\title{
BIOTURBATION-INFLUENCED FLUID PATHWAYS WITHIN A CARBONATE PLATFORM SYSTEM: THE LOWER CRETACEOUS (APTIAN-ALBIAN) GLEN ROSE LIMESTONE
}

\author{
JAMES A. GOLAB ${ }^{\mathrm{a},}$, JON J. SMITH ${ }^{\mathrm{b}}$, ALLAN K. CLARK ${ }^{\mathrm{c}}$,AND ROBERT R. \\ MORRIS $^{\mathrm{c}}$ \\ ${ }^{a}$ Department of Geology, University of Kansas, 1475 Jayhawk Blvd., rm 120, \\ Lindley Hall, Lawrence, Kansas, 66045, USA, ${ }^{*}$ jgolab@ku.edu; \\ ${ }^{b}$ Kansas Geological Survey, University of Kansas, 1930 Constant Blvd., Lawrence, \\ Kansas, 66046, USA; \\ ${ }^{c}$ Texas Water Science Center, U.S. Geological Survey, 5563 De Zavala Rd., Suite 290, San \\ Antonio, Texas, 78249, USA. \\ *Corresponding Author
}

(C) 2016. This manuscript version is made available under the Elsevier user license http://www.elsevier.com/open-access/userlicense/1.0/ 
The Aptian-AlbianGlen Rose Limestone (GRL) is an argillaceous shallow-marine carbonate deposit on the Central Texas Platform and contains the upper Trinity aquifer and the upper part of the middle Trinity aquifer. The GRL is divided into Upper and Lower GRL members, which have beenfurther subdivided into hydrostratigraphic units (HSUs). This study uses an integrated ichnological and sedimentological approach to record changes in ichnofabric index (ii) as a proxy for bioturbation within the GRL and relates these changes to fluid flow. Fluid pathways within HSUs are controlled by the complex interaction of faults and fractures, karst development, and large-scale bioturbation-influencedporosity and permeability. The effect of bioturbation-influencedporosity as an aquifer characteristic is the least studied of these factors. Postdepositional solution enhancement of ichnofossils is also common and has increased lateral and vertical fluid connectivity in some HSUs. Most GRL strata are dominated by Thalassinoides networks, but also contain Palaeophycus, Planolites, Ophiomorpha, Serpulid worm tubes, rhizoliths, andCruziana.Thalassinoides are commonly filled with coarser sediment than the surrounding matrix and act as fluid conduits within an otherwise low permeability matrix. Beds with ii3-4 and burrows with permeable fill transmit water readily. Beds with ii5-6 are commonly muddy and heavily homogenized, restricting fluid flow. Grainstone beds commonly have ii1-2 and are well cemented, restricting fluid flow to low intergranular flow. Pore systems dominated by Thalassinoides ichnofabrics, such as the GRL, are difficult to characterize on a large scale using many laboratory methods because they create heterogeneous flow paths depending on difference in permeability between the matrix and burrow fill. Understanding the effects of bioturbation-influenced porosity and permeability on subsurface fluid pathways is vital for creating a geologic and hydrostratigraphic framework for the Trinity aquifer. 
25 Keywords: Trace Fossils; Ichnology; Karst; Hydrostratigraphy; Thalassinoides 


\subsection{Introduction}

The Lower Cretaceous (Aptian-Albian) Glen Rose Limestone (GRL) forms the upper

Trinity aquifer and the upper part of the middle Trinity aquifer in south-central Texas (TX). The combined Edwards and Trinity aquifer system provides the sole source of freshwater for San Antonio, TX, the seventh largest city in the United States, and the surrounding area (Clark, 2003). It is, therefore, vital to create a robust geologic framework in order to understand the subsurface fluid pathways of the GRL for developmental planning and regulating water usage in south-central TX.

Fluid pathways within the GRL are controlled by the complex interaction of faults and fractures, karst development, and large-scale bioturbation-influenced porosity and permeability (Horvoka et al., 1994). Extensive studies have been conducted on the effects of fracturing (e.g., George, 1952; Maclay and Small, 1976, 1986; Grimshaw and Woodruff, 1986; Maclay 1989; Pantea et al., 2008) and karst (e.g., Horvorka et al, 1994; Maclay, 1995; Scanlon et al., 2003; Faith, 2004; Gary et al., 2013) on Edwards and Trinity aquifer quality; however, few studies have focused on bioturbation-influenced porosity and ichnofabricswithin these systems (i.e., Cunningham and Sukop, 2012).

Ichnofossils are common throughout the carbonate strata of south-central TX and are significant controls on fluid flow. Cunningham and Sukop (2012) showed permeability associated with Thalassinoides-dominated ichnofabrics controlled horizontal fluid flow within the overlying Edwards aquifer, where unfilled ichnofossils form interconnected fluid conduits. The mudstone and marl within the GRL; however, complicates such ichnofabric analysis as many GRL Thalassinoides are filled with carbonate mudstoneto grainstone acting eitheras barriersor conduitsrespectively. Dissolution of existing ichnofossils is also common in the GRL 
49 and may have increased the vertical and lateral fluid connectivity of some beds. Dissolution of

50 material via meteoric wateralong fluid pathways is a prominent feature in similar carbonate

51 settings (Mylroie and Carew, 1990; Cunningham et al., 2009; Wright et al., 2014) and

52 dissolution of ichnofossils has been shown to increase porosity and permeability in such systems

53 (Cunningham et al., 2009; Tonkin et al., 2010).

$54 \quad$ This study uses an integrated ichnological and sedimentological approach to record

55 changes in ichnofabric index (ii) as a proxy for bioturbation within the GRL and interprets how

56 these changes relate to subsurface fluid pathways. The GRL is a carbonate platform composed

57 of rudist reefs and subtidalto supratidal facies assigned to the Thalassinoidesichnofacies. The

58 majority of GRL strata are the dominated by coarsening-upward successions of wackestone to

59 packstone with some carbonate mudstone and grainstone. These successions have been

60 interpreted to have been deposited by a tide-dominated system and are commonly muddy with

61 low intergranular permeability. Associated rudist-dominated facies are also muddy, but contain

62 abundant fractures and have high permeability, but limited lateral extent (Petta, 1977). The GRL,

63 therefore,cannot transmit fluid through interparticle porosity easily, but may rely, in part, on

64 bioturbation-influenced porosity (Mathews, 1967; Achauer, 1977; Cunningham and Sukop,

65 2012; Golab et al., 2015). This biogenic aspect ofkarstic aquifers has generally been overlooked

66 in the literature (Cunningham et al., 2009; Cunningham and Sukop, 2011, 2012; Golab et al., 67 2015).

68

$69 \quad 2.0$ Geological Background

70 2.1 Depositional and Tectonic History 
The GRL is the uppermost formation of the Lower Cretaceous Trinity Group, which is

72 present across most of south-central TX (Fig. 1; von Roemer, 1852; Imlay, 1945). The Trinity

73 Group is a succession of three distinct, second-order,transgressive-regressive sequences

74 composedof a lower siliciclastic lowstand unit and an upper carbonate highstand unit deposited

75 on the shallow-marine Central Texas Platform, which spans from the Llano Uplift southeast to

76 the Stuart City Reef (Fig.1; George, 1952; Winter, 1961; Barnes, 1965; Stricklin et al., 1971;

77 Inden, 1974; Bebout et al., 1977; Barnes, 1981). The three sequences of the Trinity Group in the

78 study area are: 1) the Hosston and Sligo formations; 2) the Hammett Shale and Cow Creek

79 Limestone; and 3) the Hensel Sand and the Glen Rose Limestone(Fig. 2; Stricklin et al.,

80 1971).The Trinity Group is overlain by the Albian Edwards Group, a 120-180 m succession of

81 platform carbonates that accumulated north of the Stuart City Reef across most of central and

82 southern Texas (Fig.1; Rose, 1972). The GRL forms the upper Trinity aquifer and the upper part

83 of the middle Trinity aquifer, which act as a catchment for the Edwards aquifer where it is

84 exposed at the surface (Small and Lambert, 1998; Blome et al., 2007; Clark et al., 2009).

The GRL is an 120-m-thick succession of argillaceous carbonates with few beds of

86 siliciclastics and is divided into two members: the Upper and Lower GRL (Lazo and Stricklin,

87 1956; Carew, 1967; Stricklin et al., 1971; Scott et al., 2007). The Lower GRL is 70-74 m thick

88 within the study area and is characterized by m-scalebeds of mudstone and marls alternating with

89 beds of wackestone to grainstone (Clark, 2003, 2005; Clark and Morris, 2015). These beds are

90 fossiliferous and commonly contain the whole or fragmentary shells of gastropods (e.g., Nerinea

91 sp.;Tylostoma sp.), bivalves (e.g., Texigryphea sp.;Cucullaea terminalis), echinoids (e.g., Selenia

92 sp.; Hemiaster sp.)and foraminiferans (e.g., Orbitolinasp.; Milioid sp.;Adkins, 1928; Behrens,

93 1965; Clark and Morris, 2015). In some localities, LowerGRL beds grade laterally into 
94 discontinuous rudist facies dominated by Caprinid sp. The presence or absence of rudist reef

95 facies within vertical intervals of the Lower GRL was caused by changes in regional seawater 96 chemistry, as well as localized changes in depth and water currents (Petta, 1977). The Lower

97 GRL is topped by a regional “Corbula bed” (Corbula packstone-grainstone facies, this study), an $\sim 15 \mathrm{~cm}$ marker unit dominated by the tiny bivalve Eoursivivas harveyi and commonly

99 containing ripples (Scott et al., 2007; Ward and Ward, 2007). The Upper GRL is 92-119 m thick in the study area and is dominated by m-scale marly-argillaceouswackstone to packstone

101 beds and rare gypsum beds. The presence of evaporites is attributed to restricted circulation 102 conditions shoreward of the Stuart City Reef (Fisher and Rodda, 1969). Rudist-dominated facies 103 are present, but not common in the Upper GRL.

Individual beds within the GRL are heterogeneous and vary significantly laterally and vertically. Stratigraphic control has traditionally been maintained using the distinct fossil beds 106 such as the Corbula and Selenia marker beds (e.g., George, 1952; Whitney, 1952; Ward and 107 Ward, 2007; Clark and Morris, 2015). Central Texas Platform GRL strata are characterized by cyclic successions of facies grading from fine-grained mudstones and wackestones to fine- to medium-grained packstones and grainstones (Behrens, 1965; Clark 2003, 2005). Regional subsurface architecture forms clinoforms that span from the Llano Uplift to the Stuart City Reef 111 (Cleaves, 1977; Braun, 2011). extensively faulted during the Miocene, creating the Balcones Fault Zone; a northeast-southwest trending zone of normal faults that extend from central to north Texas (Fig. 1; George, 1952; Horvorka et al., 1994). Miocene faulting occurred along preexisting zones of weakness in 116 Paleozoic rocks along the Ouachita front (Collins, 1995). Most faults within the Balcones Fault 
117 Zone are high angle and form a series of en echelon fault blocks in which relay ramps are

118 common (Collins, 1995; Pantea et al., 2008).

\subsection{Hydrostratigraphy}

The Upper and Lower GRL have been subdivided into eleven hydrostratigraphic units

122 (HSUs; Fig. 2)using theporosity-based classification system defined by Choquette and Pray

123 (1970). Hydrostratigraphic units are stratigraphic divisions with distinct hydrologic

124 characteristics (Maxey, 1964; Choquette and Pray, 1970). This definition was developed because

125 there are various factors that affect aquifer fluid flow such as lithology, sedimentary structures,

126 bioturbation, and structural features (Maxey, 1964; Choquette and Pray, 1970; Clark and Morris,

127 2015).The concept of HSUs was combined with the characterization of fabric and not-fabric

128 selective porosity defined by Choquette and Pray (1970) for studies on the Edwards aquifer,

129 which divided the Edwards aquifer into eight HSUs (I-VIII; Maclay and Small, 1976; Maclay,

130 1995; Barker and Ardis, 1996; Bumgarner et al., 2012). These studies on the Edwards aquifer

131 severed as the basis for the subdivision of the GRL by Clark (2003, 2005) and Clark et al., (2009,

132 2014). The types of fabric-selective porosity within the GRL are in descending order of

133 abundance: burrowed, bedding plane, moldic, shelter, and interparticle (Clark et al., 2009, 2014;

134 Clark and Morris, 2015). The GRL also contains, in descending order of abundance, not-fabric

135 selective fracture,vug,channel, cave, andbreccia porosity (Clark and Morris, 2015). All of the

136 tidal-dominated strata of the GRL may contain one or more of these porosity types. Porosity

137 created by biologic activity (i.e., burrowed) is the least studied feature within the GRL.

The Lower GRL was subdivided into six informal units by Blome and Clark (2014). The

139 Lower GRL HSUs were named by Clark et al. (2014) as, in ascending order: the Honey Creek, 
140 Rust, Doeppenschmidt, Twin Sisters, Little Blanco, and Bulverde HSUs (Fig. 2).The Upper GRL

141 was informally subdivided into five HSUs by Clark (2003) and named by Clark et al. (2009).

142 These five units are, in ascending order: the Lower Evaporate, Fossiliferous, Upper Evaporate,

143 Camp Bullis, and Cavernous HSUs. Water well cores and petrophysical logs including gamma-

144 ray, spontaneous potential, and resistivity logs were also used to identify the 11 HSUs in the

145 subsurface (Blome and Clark, 2014; Pantea et al., 2014;Clark and Morris, 2015). Changes in

146 welllog response are relative to changes in mud content and permeability; both of which are

147 affected by the amount of bioturbation, as well as epikarst and fracture development (Zhou et al., 148 2002).

The Trinity aquifer is subdivided into the lower, middle, and upper Trinity aquifers. The 150 upper Trinity aquifer is contained within the five Upper GRL HSUs (Ashworth,1983; Clark et al., 2009). The middle Trinity aquifer is contained within the six Lower GRL HSUs, the Hensell

152 Sand, and the Cow Creek Limestone (Ashworth,1983; Blome and Clark, 2014; Pantea et al., 153 2014). The Hammett Shale is an impermeable aquitard between the middle and lower Trinity 154 aquifers. The lower Trinity aquifer is contained within the Hosston and Sligo formations 155 (Ashworth, 1983).

Due to the mud and siliciclastic material present in the GRL, wells within the Trinity 157 aquifer commonly have a lower flow rate than wells within the Edwards aquifer (Maclay, 158 1995;Mace et al., 2000). However, the Trinity aquifer covers a much larger regional extent and 159 rapid development within the Texas “Hill Country” between Austin and San Antonio has 160 brought the aquifer to the attention of local groundwater users, water purveyors, and resource 161 managers(Clark and Morris, 2015). 
163

164

\subsection{Methods}

\subsection{Field Methods}

Fouroutcrop measured sectionswere made across the study area, covering all HSUsexcept the Little Blanco and Bulverde HSUs, which were examined in core (Supplemental Data Figs. 15).Outcrop sections were measured with a hand level and a Jacob’s staff that was demarcated in decimal ft and extended up to $25 \mathrm{ft}$ in length. Beds were described lithologically, sedimentologically, and ichnologically. Lithologies were described using the classification systemof Dunham (1962) for carbonates, the Embry and Klovin (1971) classification for rudist reef material, and the Wentworth (1922) classification scale for siliciclastics. Sedimentological features and ichnofossils were examined and described in situ; some representative ichnofossil samples were collected for photographs. Ichnofossils were described using morphology, surface textures, and burrow fill (e.g., Pemberton and Frey, 1982; Hasiotis and Mitchell, 1993). Additionally, two near-complete GRL coresfrom Camp Stanley, San Antonio, TX (MW9-CC, MW5-LGR), stored at the U.S. Geological Survey’s Core Research Center in Denver, Colorado, were also described similarly to outcrop sections.

Ichnofabric indices were recorded in the field and used to interpret the percent amount of bioturbation as defined by Droser and Bottjer (1986). Ichnofabric index (ii) is a semiqualitative field interpretation of the amount of bioturbation within strata. This scale rates the amount of bioturbation from 1-6, where ii1 is a lack of bioturbation and ii6 is sediment that has been completely homogenized due to biologic activity.Ichnofabric indices of individual lithologic beds within HSUs were compared over the entire vertical extent of the GRL.

Additionally, field data collection was assisted by the use of an Apple iPad 2 loaded with geospatially registered 7.5-minute USGS topographic maps. Locations of visible and interpreted 
contacts, faults and fractures, marker units, and other areas of interest were recorded using the integrated 3G assisted global positioning system (GPS) on the iPad, which is accurate to $<1.5 \mathrm{~m}$ if cellular data service is present, as over most of the study area. Major lithologic contacts were first identified and subadjacent strata were then described.

\subsection{Laboratory Methods}

One hundred petrographic thin section samples were taken from core MW9-CC in Bexar County, TX, the approximate location of which is indicated on Figure 1.Wagner Petrographic in Lindon, Utah produced the thin sections which were $24 \times 46 \mathrm{~mm}$ in size and impregnated with clear epoxy. These thin sections were used to analyze mineralogy, cementation, micropaleontology, and microporosity.Analysis was conducted using an AmScope T490B-MT digital compound trinocular microscope with an integrated digital camera for pictomicrographs. Additionally, each thin section from MW9-CC was point counted using an Olympus BX53 microscope with an automated stepper stage controlled by PetrogLite 3.0 softwareto determine the matrix porosity of the sample and amount of cement (Conwy Valley Systems Ltd., 2011). Three hundred points were counted on each section and the results are summarized in Supplemental Data Table 1.

Plug samples from both outcrop and core were drilled and sent to Weatherford Internationalin Golden, Colorado for porosity and permeability testing via helium expansion. Core plugs were taken from GRL core MW5-LGR in Bexar County using a drill press with a diamond-tipped, 2.54 cm-diameter core bit (Supplemental Data Table 2). Outcrop plugs were taken in Kendall County using a cordless hand drill fitted with a $1.91 \mathrm{~cm}$-diameter diamond core bit and water coolant tank (Supplemental Data Table 3). Helium expansion testing usedBoyle’s 
209 law to determine the porosity, permeability, and grain volume of a sample under 400 psi

210 confining pressure (Winters et al., 1999). Results for porosity testing included ambient and

211 neutron capture gamma-ray spectroscopy porosity, air and Klinkenberg permeability, and grain

212 density.

213

$214 \quad 4.0$ Results

215 4.1 Lithofacies

216 In the study area, the GRL is subdivided into nine end-member lithofacies listed in

217 deceasing order of relative abundance: (1) nodular and massive marly wackestone-packstone

218 (Nwp); (2) cross-bedded argillaceouswackestone-packstone (Cwp); (3) fossiliferous grainstone

219 (Fgs); (4) evaporitic mudstone (Ems); (5) Corbula packstone-grainstone (Cpg); (6) rudist-

220 dominated floatstone (Rdf); (7) rudist-dominated bafflestone (Rdb); (8) laminated calcareous

221 mudstone (Lcm); and (9) carbonate-cemented sandstone (Ccs).Lithofacies characteristics are

222 summarized in Table 1 and illustrated in Figures 3 and 4. The described lithofacies are specific

223 to the study area and do not include the full extent of previously published depositional

224 environments for the GRL (e.g.,Lozo and Stricklin, 1956; Behrens, 1965; Perkins, 1974;

225 Pittman, 1989; Mancini and Scott, 2006).

226

$227 \quad 4.2$ Ichnology

228 Ichnofossils are common in the GRL and are pervasive within most beds on the Central

229 Texas Platform.Marine organisms react to a variety of physicochemical factors such as substrate

230 composition,nutrient availability, salinity, turbidity, temperature,and oxygen (e.g., Ekdale and

231 Bromley, 1984a,b; Bromley and Ekdale, 1986; Uchman, 1995). Ichnofossils are listed in 
232 decreasingrelative order of abundance and include: (1) Thalassinoides;(2) Palaeophycus;(3)

233 Planolites, (4) Ophiomorpha, (5) rhizoliths,(6) Serpulid traces, and (7) Cruziana. The

234 relationships between ichnofossils and lithofacies are summarized in Table 1.

235

236

4.2.1Thalassinoidesisp.(Fig. 5A-C)

Thalassinoides are unlined, three-dimensional boxworks of cylindrical burrows. These traces range from $\sim 0.5-2.5 \mathrm{~cm}$ in diameter within the GRL. Some burrows are $>4 \mathrm{~cm}$ in diameter

239 due to solution enhancement in locations proximal to karstic features. Infill of burrows is similar 240 to surrounding matrix or overlying beds and may consist of mudstone or wackestone-

241 grainstone.Thalassinoidesin the GRL are commonly multigenerationally tiered, with burrow

242 density decreasing upsection in individual beds (Bromley and Ekdale, 1986). These networks

243 comprise the majority of ichnofossils in all GRL lithofacies, but are most prevalent in

244 wackestone-packstone facies.Cunningham and Sukop (2012) showed that abundant

245 Thalassinoides ichnofabrics in the Edwards Group affected lateral fluid flow within beds, but the

246 mudstone and siliciclastic sediment within the GRL complicates such direct interpretations.

247 Computer modeling has also shown that Thalassinoides networks begin to continuously

248 interconnect when burrows comprise as little as $10 \%$ of the strata (La Croix et al., 2012). These

249 Thalassinoides networks provide the majority of bioturbation-influenced fluid pathways within 250 the GRL.

252 4.2.2 Palaeophycusisp. (Fig. 5D)

Palaeophycus are mud-lined, cylindrical burrowswith infill similar to the matrix or

254 overlying unit. These traces range from $0.5-2.0 \mathrm{~cm}$ in diameter within the GRL. The mud lining 
255 is thin ( 1 mm), micritic, and commonly dark yellow (Fig. 5D). Palaeophycusare commonly

256 found associated with,and have similar sediment infill to,Thalassinoides networks. The infill

257 within the traces shows no evidence of active backfilling such as meniscae and was likely

258 deposited with overlying sediment. Palaeophycus is most often found overlaying significant

259 Thalassinoides networksin beds with less bioturbation.Because of their similar morphology to

260 and proximal associationwith Thalassinoides,these Palaeophycus were likely made by the same

261 tracemakers. Palaeophycusare commonly found above Thalassinoides networks in marly

262 wacketone-packstone facies. Palaeophycuscommonly havecoarse-grained, permeable infill and

263 likely act as fluid pathways.

264

265 4.2.3 Planolitesisp. (Fig. 5E-F)

266 Planolities are unlined, mud-filled,cylindricalburrows oriented parallel to bedding planes

267 (Fig. 5E). These burrows vary in diameter slightly along their length and range from $0.2-1.5 \mathrm{~cm}$

268 in diameter.Planolitesare commonly found isolated from Thalassinoides networks within beds

269 with relatively low bioturbation. The matrix of these beds varies from mudstone to packstone

270 and is commonly argillaceous, though Planolites isfound associated with detrital conglomeratic

271 material in one bed (Fig. 5F). Planoliteshave smooth walls and rarely branch or overlap.The

272 infill of Planolites is muddy and distinct in color and fabric from the surrounding matrix and

273 overlying units. The muddy infill of Planolites within the GRL means that they will act as fluid

274 barriers.They are common in beds near the top of the Lower GRL and likelydo not play a

275 significant role in overall fluid flow.

276

277 4.2.4 Ophiomorphaisp. (Fig. 6A-B) 
Ophiomorpha are pellet-lined,cylindricalburrows that may branch and range from 2.5-3.0

279 cmin diameter (Fig. 6A).Burrow infill is similar to surrounding matrix and pellets are composed

280 of mud, but may contain various small clasts. Ophiomorpha are commonly horizontally-oriented,

281 found associated with Thalassinoides networks, and may grade into unlined burrows within

282 units. Similar to Thalassinoides, Ophiomorpha may branch and be multigenerationally

283 tiered(Fig. 6B; Bromley and Ekdale, 1986). These ichnofossilsare found within higher-energy

284 crossbedded wackestone-packstone facies in the Upper GRL and within units with larger clast

285 sizes on average.These traces were likely made by the same tracemaker as Thalassinoides and

286 Palaeophycus. The mud pellets are simple peloids and are created by the tracemaker to increase

287 the structural integrity of the burrow (Uchman, 1995;Vaziri and Fürsich, 2000). Many

288 Thalassinoides burrows within the GRL may have originally been Ophiomorpha, but have been

289 altered by subsurface and meteoric water flow, removing evidence of the pelleted lining

290 (Bromley and Frey, 1974; Myrow, 1995). Also similar to Thalassinoides, these traces likely act

291 as significant fluid pathways in both the Upper and Lower GRL, particularly within crossbedded

292 strata. Additionally, Ophiomorpha-dominated ichnofabrics have been shown to be the primary

293 hydrologic driver of the similar karstic Biscayne aquifer of southern Florida (Cunningham et al., 294 2009)

295

296

4.2.5 Rhizoliths (Fig. 6E-F)

297

Root traces have several different forms within the GRL, and include rhizoliths,

298 rhizohaloes, and rhizocretions. Generally, these are tapered traces that extend downward from

299 subaerial exposure surfaces into underlying strata and may crosscut underlying bedding surfaces.

300 True rhizoliths are found in muddy units and have distinct downward tapering morphologies and 
301 wood-like textures in cross-section (Fig. 6E). Some rhizoliths have a light-colored rim around

302 the entire structure called rhizohaloes (Fig. 6E). Some beds show light colored discoloration

303 interpreted to be rhizohaloes with no remaining fossilized woody material. Rhizocretions have a

304 nodular texture that appears as interlocking and overlapping spheres that contain root hair traces

305 in cross section (Fig. 6F). Nodular beds showing rhizocretions are typically $<0.5 \mathrm{~m}$ thick.

306 Rhizoliths are associated with only insipient soil development in the study area, but enough

307 development to concentrate clay minerals via illuviation in subaerially exposed horizons (Kraus

308 and Hasiotis, 2006; Smith et al., 2008; Hasiotis and Platt, 2012).Beds and surfaces suggesting

309 subaerial exposure and showing rhizoliths are rare in the study area, but previous studies have

310 shown that such beds increase in abundance northward on the Central Texas Platform (Lozo and

311 Stricklin, 1956; Perkins, 1974; Ward and Ward, 2007). Rhizoliths are therefore potential

312 hydrologic indicators as the increased amount of clay may act as a barrier to fluid flow.

314 4.2.6Serpulid tubes (Fig. 6C-D)

315 Serpulid tubes are carbonate cement-lined, cylindrical, coiled tubes filled with mudstone

316 that are oriented parallel to bedding planes. Single tubes may be tens of cm long and may coil on

317 themselves several times (Fig. 6C). The tubes have a distinct brown-tan color with transverse

318 striations and mud infill that is concentrically laminated (Fig. 6D). Serpulid tubes are commonly

319 found attached to bivalve and gastropod shells. The tubes may have been filled with sediment

320 after burial and the presence of sparry infill acts as a geopetal in thin section (Fig. 6D).

321 Similarmodern tubes are created by annelid worms of the genus Serpula(Vinn et al., 2008).These

322 tubes are found within muddy, fossiliferous units that consist primarily of nodular marly

323 wackestone and packstone and play a very minor role in fluid flow. 
4.2.7Cruziana isp. (Fig. 6G)

Cruziana are bilobate furrows with a medial ridgeand transverse, ridged striations that

327 gently curve back away from the direction of travel. Cruziana traces in the GRL average $\sim 13 \mathrm{~cm}$

328 wide and range from 47.4-59.3 cm long (Fig. 6G). These furrows are $\sim 2-3 \mathrm{~cm}$ deep with

329 preserved mounding and drag marks along the sides of trace. All observed Cruziana are

330 associated with crossbedded wackestone-packstone at a single location in Comal County and

331 several of the traces overlap on a single bedding surface. Other ichnofossils, such as

332 Thalassinoides, are relatively rare in the associated strata. The tracemaker for these Cruziana in

333 the GRL has previously been interpreted as horseshoe crabs (Ward and Ward, 2007). This study;

334 however, interprets the tracemaker as a different large arthropod or possible isopod because

335 horseshoe crab trackways generally lack distinct scratch marks such as the curved striations seen

336 in these trackways, but commonly have individual limb traces (Babcock et al., 2000). Although

337 these traces are associated with otherwise transmissive facies, the location of these trackways

338 along bedding planes and their limited preserved extent indicates that these ichnofossils have no

339 effect on fluid flow.

\subsection{Ichnofabric index analysis}

The GRL is muddy and has low intergranular porosity; therefore, fluid pathways are

343 often larger-scale features such as faults and fractures, ichnofossils, and molds. Ichnofabric

344 indices (ii), as a measure of ichnofossil density and overall bioturbation, can be used as

345 hydrologicindicators within the GRL and similar karstic aquifers (Fig. 7).An ii1 unit will have no

346 bioturbation (Droser and Bottjer, 1986) and fluid flow will be restricted to intergranular porosity 
347 if faults and karstic development are not present. Beds with ii2 have less than $10 \%$ of their total

348 volume bioturbated; such beds within the GRL commonly contain Palaeophycus,Planolites,

349 andvisible sedimentary structures (Fig. 7A). Beds with ii3 have 10-40\% percent of their total

350 volume bioturbated; most GRL ii3 beds are dominated by Thalassinoides networks and have few

351 to no visible sedimentary structures (Fig. 7A). Beds in the GRL that are ii4 have 40-60\% of their

352 total volume bioturbated, are dominated by Thalassinoides networks, and generally have no

353 sedimentary structures visible (Fig. 7B). Beds with ii5 have over $60 \%$ of their volume

354 bioturbated; some individual Thalassinoides are visible within these beds (Fig. 7C). Beds that are

355 completely homogenized and nodular in appearance are assigned to ii6 and dominated by

356 cryptobioturbation (Fig. 7D).

357 Thalassinoides-dominatedichnofabrics become interconnected throughout beds at ii3 and 358 above (La Croix et al., 2012). Beds within the wackstone-packstone facies in the GRL that have 359 ii3-4 containThalassinoides networks that may act as fluid pathways. In fine-grained facies; 360 however, Thalassinoides are often infilled with mud and do not increase overall porosity. Beds

361 that are ii5-6 are generally homogenized and donot transmit fluids easily. Ichnofabric index must 362 therefore be examined in conjunction with lithology, porosity, and permeability characteristics of 363 stratato infer whether beds are transmissive or confining. The ii trends, porosity characteristics, 364 and interpreted transmissivity within the individual HSUsof the Lower and Upper GRL are 365 described below (Fig. 8) and summarized in Table 1.

367 4.3.1 Lower Glen Rose Limestone

The Lower GRL is primarilycharacterized by coarsening-upward successions of marly

369 wackestone to packstone facies that grade laterally into discontinuous rudist-dominated 
370 bafflestone and floatstone facies (Fig. 8). The Lower GRL has been subdivided into six HSUs,

371 which have been designated as either transmissive or confining based on porosity characteristics,

372 as well as lithology (Table 1; Clark et al., 2014; Clark and Morris, 2015). Generally, transmissive

373 units have been defined based on the presence of wide-spread fracture porosity and karstic

374 development; however, trends in bioturbation-influenced porosity can also be seen in these units

375 (Clark et al., 2014) The Lower GRL includes, from stratigraphically lowest to highest, the Honey

376 Creek, Rust, Doeppenschmidt, Twin Sisters, Little Blanco, and Bulverde HSUs.

377 Transmissive HSUs - Lower GRL transmissive units include the Honey Creek,

378 Doeppenschmidt, and Little Blanco HSUs. These HSUs consist of tidal-dominated, m-scale

379 successions of coarsening-upward nodular and massive marly wackestone-packstone beds with

380 ii4-5 and some identifiable Thalassinoides networks (Table 2; Fig. 9). These successions grade

381 upsection into marly wackestone-packstone with ii3-4 characterized by open and wackestone-

382 packstone-filled Thalassinoides networks. Some beds of laminated calcareous mudstone with ii1

383 are located at the base of successions and grade upsection into the more typical nodular

384 wackestone with ii4-5 (Table 2; Fig. 9).In some locations, transmissive HSUs grade laterally

385 into discontinuous patch reefs consisting of rudist-dominated floatstone and bafflestone having

386 ii1-ii2, with some Planolites observed in the mudstone matrix of floatstones. Although the tidal-

387 dominated strata of transmissiveHSUs have less permeability than the rudist facies, bioturbation-

388 influenced porosityis likely connected throughout the units and is a major component of this

389 unit’s transmissivity.

390

While transmissive strata share the above characteristics, unique features are observed in

391 each HSU. The bottom $~ 6.7 \mathrm{~m}$ of the Honey Creek HSU (Fig. 9) consists of the typical

392 successions described; however,the top $\sim 3 \mathrm{~m}$ of the unit has lower ii and consists of interbedded 
393 laminated calcareous mudstone and nodular wackestone with ii1-2 and containing

394 Palaeophycuswith some Thalassinoides networks. While defined as a transmissive unit, most of

395 the bioturbation-influenced porosity of the Honey Creek HSU appears to be restricted to the

396 bottom $6.7 \mathrm{~m}$ of the unit in beds with ii3-4. Most fracture and karstic development also appears

397 in the lower portions of the Honey Creek HSU (Clark and Morris, 2015). The Doeppenschmidt

398 HSU also consists of wackestone-packstone facies typical of transmissive units, but contains less

399 mud than the Honey Creek HSU and should have higher permeability as a result(Fig. 8). The

400 Little Blanco HSU contains some successions that grade upward into crossbedded wackestone-

401 packstone with ii1-2. Therefore, fluid flow is restricted to intergranular porosity and is lowin

402 these less-bioturbed units. Additionally, fluid flow is also likely restricted in the top 1.8 $\mathrm{m}$ of

403 the Little Blanco HSU where muddier wackestone units are interbedded with ii1-2 laminated

404 calcareous mudstone.

405 Confining HSUs - Lower GRL confining units consist of the Rust, Twin Sisters, and

406 Bulverde HSUs (Fig. 8). Confining HSUs usually consist of m-scale beds of nodular, marly

407 wackestone with ii5-6 that are thoroughly homogenized by pervasive cryptobioturbation with

408 some identifiable Thalassinoides(Table 2; Fig. 10). Unlike transmissive HSUs, confining units

409 generally do not display coarsening upward trends, contain more mud, and show less fracture

410 porosity. Similar to transmissive units, confining HSUs in some locations grade laterally into

411 discontinuous patch reefs consisting of rudist-dominated floatstone and bafflestone having ii1-

412 ii2 (Fig. 8). These patch-reefs have high moldic and fracture porosity, but because of their lateral

413 isolation within otherwise confining strata they cannot transmit water within the HSU. These

414 patch reefs may; however, transmit water vertically between transmissive units(Hunt and Smith, 415 2010). 
417 displays some coarsening upward successionssimilar to transmissive units. Burrow infill in the

418 Rust HSU ranges from wackestone-packstone, and the uppermost beds contain

419 Palaeophycusand mud-filled Planolites. These mud-filled ichnofossils in the Rust HSU do not 420 increase bioturbation-influenced porosity as much as seen in transmissive units. The Bulverde

421 HSU is complex - it consists mainly of coarsening-upward successions of nodular and

422 crossbedded wackestone-packstone withoverall well-developedbioturbation-influenced porosity

423 (ii4-5) similar to transmissive units. However, it contains interbedded laminated calcareous

424 mudstoneintervals (ii1) at the base and is capped by Corbula packstone-grainstone (ii1), both of

425 which severely restrict fluid flow. Although the Bulverde HSU has been classified as a confining

426 unit, thetransmissive middle portion contains well-developed biogenic and moldic porosity and

427 may transmit significant amounts of water.Thus, the Bulverde HSU may be better classified as a

428 semi-confining unit.

429

430

\subsubsection{UpperGlen Rose Limestone}

431

The Upper GRL primarily consists of coarsening upward successions of marly

432 wackestone to packstone facies similar to the Lower GRL, but contains abundant evaporites

433 andfew rudist dominated patch reefs (Table 2; Fig. 8). Conditions during the deposition of the

434 Upper GRL appear to have never fully returned to the normal marine conditions seen in the

435 Lower GRL after the deposition of the Corbula bed (Fisher and Rodda, 1969). The Upper GRL

436 has been subdivided into five HSUs: the Lower Evaporite, Fossiliferous, Upper Evaporite, Camp

437 Bullis, and Cavernous HSUs (Clark, 2005; Clark et al., 2009). Transmissive HSUs are associated

438 with significant evaporitic beds and karstic development. Confining units in the Upper GRL are 
439 lithologically and ichnologically similar to transmissive units in the Lower and are interbedded 440 with the karstic transmissive units.

Transmissive HSUs—Upper GRL transmissive units includethe Lower Evaporite, Upper

442 Evaporite, and Cavernous HSUs. TheseLower Evaporite and Upper EvaporiteHSUs areeach 3

$443 \mathrm{~m}$ thick and characterized by evaporitic mudstone with ii1-2 andpervasive dissolution features in

444 both evaporites and carbonates (Table 2).Both the Lower and Upper Evaporite HSUs also

445 contain significant moldic porosity and karstic development from the dissolution of evaporitic

446 minerals (Clark, 2005; Clark et al., 2009). These Evaporite HSUs were deposited in brackish

447 conditions preventing wide-spread bioturbation in this unit (Fisher and Rodda, 1969).

448

The Cavernous HSU overlies the Camp Bullis HSU and is highly transmissive because of

449 significant karstic and cave features present in the subsurface (Clark, 2005). Defined in core and

450 through geophysical analysis (Clark, 2005) in northern Bexar County, TX (see Fig. 1), the

451 Cavernous HSU is typically less than $10.5 \mathrm{~m}$ thick, has a limited lateral extend and is not present

452 at the surface through most of the study area. This HSU consists of marly wackestone-

453 packstone successions similar to transmissive units in the Lower GRL, but has been significantly

454 faulted and fractured. The high permeability of the overlying Edwards Group has introduced

455 meteoric water into these faults and fractures creating karstic features (Smith et al., 2005; Clark,

456 2004). Pervasive solution enhancement has destroyed most evidence of bioturbation in this unit,

457 particularly in close proximity to faults and fractures. Within the GRL, the Upper GRL HSUs

458 display more solution enhancement due to the high infiltration rates of the overlying Edwards

459 aquifer (Maclay, 1995; Smith et al., 2003; Clark, 2004). The steep, near vertical orientation of

460 the Balcones Fault Zone faults has allowed for the introduction of meteoric water deep within the 
461 aquifer, which has infiltrated laterally from the faults following interconnected Thalassinoides

462 networks and other ichnofossils and molds within the GRL.

Confining HSUs - The Upper GRL confining units are the Fossiliferous and Camp Bullis

464 HSUs (Fig. 8). Similar to Lower GRL transmissive units, the Fossiliferous and Camp Bullis

465 HSUs consist of coarsening-upward successions that grade from nodular, marly wackestone with

466 ii5-6 dominated by pervasive cryptobioturbation to marly wackestone-packstone with ii3-4 and

467 pervasive Thalassinoides networks (Table 2; Fig. 11). These Thalassinoidesare commonly

468 infilled with wackestone-packstone from overlying units. Additionally, sequence bases may

469 contain thin beds of laminated calcareous mudstone with ii1. These HSUs share many

470 similarities with the transmissive units of the Lower GRL and contain well-developed burrow

471 and bedding-plane porosity with some fracture development (Fig. 11; Clark, 2005; Clark et al.,

472 2009). These units,however, are significantly less permeable than the evaporitic and Cavernous

473 HSUsbecause of their mud content and lack of dissolution features and fractures (Clark, 2005;

474 Clark et al., 2009).

475 The Fossiliferous HSU is fairly muddy but coarsening-upward patterns of successions are

476 observed, unlike most confining units in the Lower GRL. This HSU contains significant moldic

477 porosity due to the dissolution of shell material, as well as well-developed bioturbation-

478 influenced porosity. This unit, however, does not transmit water as readily as the overlying and

479 underlying evaporite units. Numerous seeps and springs are found at the top of this unit,

480 indicating diverted flow of meteoric, similar to confining units in the Lower GRL. The

481 Fossiliferous HSU does grade laterally into rudist patch reef strata with high fracture and moldic

482 porosity in northern Bexar County. 
The Camp BullisHSU (Fig. 11)contains less mud than the other HSUs and successions

484

485

486

487

488

489

490

491

492

493

494

495

496

497

498

499

500

501

502

503

504

505

within it grade from typical cryptobioturbated beds seen in the Fossiliferous HSU to marly

wackstone-grainstone with ii3-4 with abundant Thalassinoides and Ophiomorpha. The

grainstone at the top of many of these successions shows some crossbedding and has ii1 and is well-cemented leading to low intergranular porosity. Similar to transmissive units in the Lower GRL, the muddier ii5-6 beds at the base of successions in the Camp Bullis HSU likely prevent significant vertical fluid flow but water is transmitted laterally in overlying beds with ii3-4 to seeps and springs and to fractured areas.

The Fossiliferous and Camp Bullis HSUs have previously been defined as confining units because of diversion of ground and meteoric water seen at the surface of these units (Clark, 2005; Clark et al., 2009). This is likely because of the comparatively high permeability seen in the evoporitic and Cavernous HSUs, as well as the large amount of meteoric water that can quickly infiltrate the overlying Edwards Group. However, the similarity of these two units both ichnologically and lithologically to Lower GRL transmissive units and well developed porosity likely allows for the transmission of significant amounts of water. These two units may; therefore, be better described as "semi-confining HSUs”.

\subsection{Solution enhancement of ichnofossils}

Solution enhancementin the GRL has increased connectivity of fractures and burrows and caused autoclastic brecciation and cavern development in many cases. Multiple stages of solution enhanced features are preserved and forming in the GRL (Fig. 12). In the typical coarsening upward sequence, most ichnofossils are filledwith sediment sourced from overlying strata that is coarser than the surrounding matrix. This initial condition is shown in figure $12\left(\mathrm{~T}_{1}\right)$. 
506 This focuses water flow, particular from meteoric water, through the ichnofossil networks and

507 will dissolve the matrix surrounding the burrow over time (Fig. 12; $\mathrm{T}_{2}$ ). Meteoric water is not in

508 equilibrium with the carbonate content of the surrounding matrix and will thus widen and further

509 interconnect the burrow networks across the three-dimensional extent of the bed (Fig 12; $\mathrm{T}_{3}$ ).

510 These solution-enhanced burrow networks may subsequently either be filled with sediment (Fig

511 12; $\mathrm{T}_{4 \mathrm{a}}$ ) or continue to have the matrix dissolved by infiltrating meteoric and ground water (Fig.

512 11; $\mathrm{T}_{4 \mathrm{~b}}$ ). If exposed, infilled solution enhanced burrows may weather differentially from the

513 surrounding matrix and be preserved in positive relief (Fig. 12; $\mathrm{T}_{5 \mathrm{a}}$ ). Alternatively, dissolution

514 may continue until the matrix cannot support the overburden and the sediment compacts,

515 evidenced by a bed of brecciated sediment (Fig. 11; $T_{5 b}$ ).

516 Solution enhancement features are most significant in the GRL within close proximity to

517 faults and fractures and in beds associated with karstic development. The Upper GRL HSUs are

518 more solution enhancedthan Lower GRL HSUs due to the high infiltration rates of the overlying

519 Edwards aquifer (Hanson and Small, 1995; Maclay, 1995; Clark, 2004). The near vertical faults

520 of the Balcones Fault Zone transmitted meteoric water into the subsurface where it infiltrated

521 laterally into the strata along interconnected Thalassinoides networks and other ichnofossils and 522 molds.

523

$524 \quad 5.0$ Discussion

525 Ichnologic assessment is important in aquifer and reservoir characterization,however,

526 most studies have been conducted in siliciclastic units (e.g., Keswani and Pemberton, 2007;

527 Tonkin et al., 2010; Gingras et al., 2012). Bioturbation commonly decreases porosity and

528 permeability in both siliciclastic and carbonate aquifers that contain significant intergranular 
529 flow (e.g., Gingras et al., 2004; 2012).Karstic aquifers such as the Edwards and Trinity Groups;

530 however, cannot transmit significant quantities of fluid through interparticle porosityand rely on

531 bioturbation to create porosity and lateral fluid pathways (e.g., Mathews, 1967; Gingras et al.,

532 1999; Cunningham and Sukop, 2011; Baniak et al. 2013; Golab et al., 2015).Although previous

533 authors have conducted ichnological assessment of some carbonate hydrocarbon reservoirs (e.g.,

534 Gingras et al., 1999, 2004; La Croix et al., 2011; Baniak et al., 2013), thebiogenic aspect of

535 karstic aquifers has been overlooked in the literature (Cunningham et al., 2009; Cunningham and

536 Sukop, 2011, 2012; Golab et al., 2015; Clark et al., 2016). The GRL is a dual-permeability

537 system and absent fracture and karstic porosity, ichnofossils with coarse-grained infill are the

538 primary fluid pathways throughout most strata and are a significant factor in directing water

539 between major faults and karstic features. All GRL beds have been shown to produce hydraulic

540 head in water wells, even those that have been classified as confining and lack significant karstic

541 features (Clark, 2003; Hunt and Smith, 2010).

542

5435.1 Glen Rose Limestone depositional environment

$544 \quad$ The development of Thalassinoides networks is particularly common and abundant in

545 tidal-dominated carbonate platform strata (e.g., Myrow, 1995). Common Thalassinoides

546 tracemakers in modern carbonate settings include Callianassa sp., decapod crustaceans and other

547 arthropods (Sheehan and Schiefelbein, 1984; Myrow, 1995). Similar to Thalassinoides,

548 Ophiomorpha is common in high-energy, shallow marine systems (Uchman, 1995).

549 Ophiomorpha are often found associated with rapid deposition in a high-energy, wave-

550 dominated environment. 
The Lower GRL was deposited in shallow subtidal-supratidal environments with some

552

553

554 555 556 557 558 559 560 561 562 563 564 565 566 567 568 569 570 571

572 limited lateral extent of less than $300 \mathrm{~m}$ across (Petta, 1977). The talus slopes of rudist patch 573 reefs commonly form on top of packstones and grainstones that are deposited laterally from the 
574 associated reef. Previous studies on rudist reefs in the GRL showed that Caprinid sp. likely

575 formed in <5 m water depth (Perkins, 1974; Petta, 1977).

576

5775.2 Hydrologic effects of Thalassinoides-dominated ichnofabric

578 Strata within the GRL contain significant amounts of mud and cement, leading to low

579 intergranular porosity. Faults and karstic features have created most of the vertical fluid 580 pathways within the Trinity aquifer and allow meteoric water to enter the subsurface (e.g.,

581 George, 1952; Maclay and Small, 1976; Horvorka et al, 1994; Faith, 2004;Pantea et al., 2008).

582 Lateral fluid flow within beds; however, is more difficult to characterize and is primarily 583 controlled by Thalassinoides networks. Baniak et al. (2013) showed that Thalassinoides584 dominated ichnofabrics are more commonly interconnected horizontally and only become 585 vertically connected throughout a stratum after pervasive bioturbation. Such Thalassinoides586 dominated ichnofabricsact as conduits for fluids in the absence of faults or karstic development. 587 These ichnofossils were also the precursor to most vug and channel porosity due to solution588 enhancement of burrow networks, and facilitated the development of widespread moldic 589 porosity.

La Croix et al. (2012) showed that Thalassinoides networks begin to become

591 interconnected throughout the three-dimensional extent of a stratum at ii3 and above. This model 592 matches well with the ichnofabric index trends seen in this study, where ii3-4 beds in the GRL 593 are interpreted to be the most transmissive units.In Thalassinoides-dominated ichnofabricslateral 594 connectivity may exist at ii3, though vertical connectivity is generally only associated with ii5 595 and above(Baniak et al., 2013). Cunningham and Sukop (2010) showed that the Thalassinoides596 dominated ichnofabrics of the overlying Edwards aquifer significantly increase permeability; 
597 however, the amount of mud and heterogeneity observed in the GRL makes this correlation less

598 direct. Defining fluid pathways within theGRL requires the combined use of ichnofabric indices,

599 lithology, and structural features. Each of the eleven GRL HSUs is unique, but most transmissive

600 units show similar trends within beds of upward coarsening in grainsize and decreasing

601 ichnofabric indices (Fig. 9-10).

602 While each HSU displays some distinct hydrologic characteristics, most contain 603 successions of decreasing-upward ii and show that biogenic fluid flow is restricted on a smaller 604 scale within each GRL fifth-order sequence (Table 2; Figs. 9 and 11). The bases of 605 successionsarecommonly muddy andconsist of nodular strata with ii5-6. The ichnofossils at the 606 bases of successions are dominated by multigenerationally tiered Thalassinoides networks. Much 607 of the nodular appearance of these basal beds is attributed to cyrptobioturbation. The middle 608 portionsof successionsare commonly characterized by strata with ii3-4 composed of

609 Thalassinoides networks as well as Ophiomorpha, and occasional Palaeophycusand 610 Planolites.These zones with ii3-4 are the most prominent area of biogenic fluid flow within the

611 GRL as they are both interconnected throughout the strata and are commonly filled with infill 612 coarser-grained than the surrounding matrix (La Croix et al., 2012; Baniak et al., 2013). The tops 613 of successionsmay consist of massive to crossbedded packstone-grainstone with ii1-2 and 614 contain Palaeophycusand Planolites as dominant traces. Fluid flow within these upper, low ii 615 strata is restricted to intergranular pore space.While these upper beds contain less mud, they have 616 significant amounts of sparry cement; therefore, permeability is still low. 617

6185.3 Quantifying the hydrologic characteristics of dual-permeability systems 

laboratory methods, such as point-counting and helium-expansion porosity testing, were

621 developed to measure intergranular pore space of the matrixmaterial and do not accurately 622 characterize the large-scale fluid pathways seen in the GRL (Fig. 8 and Table 1). No direct 623 correlation could be observed between point-counted matrix porosity and the larger-scale 624 hydrologic trends observed within the HSUs (Supplemental Table 1). Average porosity from 625 point counts averaged only 5.27\%, and showed no significant difference between different 626 facies. Helium-expansion porosity and permeability are also limited to small-scale matrix and 627 fracture porosity, but some observable trends could be seen between lithofacies (Supplemental 628 Tables 2-3). The results from the helium expansion testing averaged $17.6 \%$ porosity and 14.6 $629 \mathrm{mD}$ permeability. Crossbedded wackestone-packstone (0.69 mD) and evaporitic units $(0.049)$ 630 have the lowest measured permeability whereas fossiliferous grainstone $(39.4 \mathrm{mD})$ has the 631 highest.

The hydrologic flow observed in the GRL (Hunt and Smith, 2010) is at least 3 orders of 633 magnitude greater than can be explained by permeability values measured from helium 634 expansion and point counting of the matrix. The most extreme example of this is within the 635 Lower and Upper Evaporite HSUs, which are interpreted to have the highest permeability in the 636 GRL based on fluid flow, but contain the lowest measured helium expansion permeability 637 values. This discrepancy in the Evaporite HSUs is likely due to abundant fractures. The other 638 HSUs within the GRL; however, are dominated by ichnofossils instead of fractures. Unlike 639 fracture-dominated dual-porosity systems, bioturbation-influenced pore systems are more 640 heterogeneous and create variable flow depending on the difference in permeability between the 641 matrix and burrow fill (Gingras et al., 1999; Baniak et al., 2013). 
643 Biscayne aquifer of southern Florida used x-ray tomography scans of full-diameter core samples

644 ( $\sim 10 \mathrm{~cm}$ diameter) to measure the porosity of large-scale burrow networks. These studies then

645 used lattice Boltzmann equations to estimate vertical and lateral permeability (Cunningham et

646 al., 2009). Although such datasets are, as of yet, unavailable for this study, the lithological and

647 ichnological similarity of the GRL with the Biscayne aquifer means that values for the large-

648 scale burrow permeability can be approximated for GRL strata.Cunningham et al. (2009) and

649 Cunningham and Sukop (2011) estimated permeability values greater than five orders of

650 magnitude higher than any previous study on the Biscayne aquifer system. Strata with ii3 were

651 shown to have an average permeability of $8.2 \times 10^{7} \mathrm{mD}$, ii 4 units averaged $2.7 \times 10^{9} \mathrm{mD}$, and ii5

652 strata averaged $8.6 \times 10^{9} \mathrm{mD}$ (Cunningham et al., 2009). Although these numbers cannot be

653 directly related to the GRL because the Biscayne aquifer’s Ophiomorpha-dominated strata

654 contain less mud and siliciclastic material, they illustrate the effect large-scale bioturbation-

655 influenced porosity can have on karstic aquifer systems and may be used as a template for future

656 studies on the Edwards (Cunningham and Sukop, 2012) and Trinity aquifers. Furthermore, the

657 Biscayne may be more lithologically and ichnologically similar to the Edwards Group, as both

658 contain less mud and siliciclastic content than the GRL.

659

660

5.4 Solution-enhancement and karstic development

The solution enhancement of ichnofossils has also played a role in the development of

662 GRL fluid flow. Introduction of meteoric water likely began with the exhumation of strata along

663 the normally faulted Balcones Fault zone during the Miocene (Horvorka et al. 1994; Clark et al.

664 2009).Solution enhancement by dissolution of material in contact with fluid pathways is a 
665 prominent feature in carbonate systems (e.g., Mylroie and Carew, 1990), and many GRL fluid 666 pathways show evidence of having been enhanced by meteoric and groundwater

667 flow.Dissolution in pre-existing three-dimensional geometric patterns of ichnofossils has

668 significantly increased the lateral and vertical permeability of most transmissive HSUs by further

669 interconnecting Thalassinoides networks and widening fluid pathways. Within areas where such

670 dissolution is extensive, complete dissolution of ichnofossils results in the formation of karstic 671 features.

672 Karstic development, while primarily controlled by faulting and fracturing (Horvorka et

673 al, 1994; Maclay, 1995; Faith, 2004), is influenced also by the presence or absence of

674 ichnofossils (Keswani and Pemberton, 2007). Hydrostratigraphic units within the GRL that

675 contain significant fault and fracture porosity have commonly been defined as the most

676 transmissive(Clark, 2003, 2005; Clark et al., 2009; Clark et al., 2015). Additionally, karstic

677 features associated with fractures are significant fluid pathways and catchments(Clark, 2003, 678 2005; Faith, 2004; Pantea et al, 2014). Bedswith well-developed biogenic networks transmitted

679 water laterally away from faults and fractures. This action aided in karstic development within 680 transmissive bioturbated beds.These features can be observed easiest in the Lower GRL Honey 681 Creek HSU and was a likely major component in the development of the Upper GRL Cavernous 682 HSU.

683

$684 \quad 6.0$ Conclusions

Large-scale bioturbation-influenced porositysuch as burrows, borings, and nodular

686 preservation of bioturbationis one of several factors that affect fluid flow within the GRL of the

687 Trinity aquifer; however, its significance in karstic aquifers and reservoirs has not been 
exploredby many authors. While faulting and fracturing and karstic development are commonly the most prevalent fluid pathways within aquifers that lack significant intergranular porosity and permeability, biogenic fluid pathways (i.e., burrows) act as conduits to move fluids laterally between faulting and fracture features. Bioturbation-influenced porosity is of particular interest to carbonate aquifers, many of which contain interconnected Thalassinoides or Ophiomorpha networks (e.g., Mazzullo and Chilingarian, 1996;Cunningham et al., 2009).

Previous studies have shown Thalassinoides-dominated ichnofabrics tend to increase the lateral connectivity of beds by creating interconnected 3-dimensional fluid pathways of either open burrows or burrows with permeable fill (e.g.,Cunningham and Sukop, 2012; Baniak et al., 2013). The muddy and siliciclastic input present during GRL deposition; however, complicates such a straight-forward correlation. Transmissivebeds in the GRLbeds have ii3-4 and burrows are commonly open or have permeable fill. Beds with ii5-6 are commonly muddy and heavily homogenized, and restrict fluid flow. Additionally, grainstone beds commonly have ii1-2 and are cemented, restricting fluid flow to low intergranular flow.

Characterizing the lateral fluid pathways requires the integration of lithology, structural and karstic features, and ichnology. The overall transmissive or confining nature of hydrostratigraphic units in the GRL depends on the ichnofabric index, fracture density, and karstic features both within the beds and in the overall stratigraphy. For example, confining beds in the Upper GRL are lithologically and ichnologically similar to transmissive beds in the Lower GRL (see figs. 9 and 11). The Upper GRL contains evaporites and significantly more karstic development than the Lower GRL, meaning that transmissive units are more commonly characterized by evaporites with significant dissolution features. Although the confining units in the Upper GRL contain significant bioturbation-influenced porosity and less mud than Lower 
711 GRL transmissive units, they are significantly less permeable than the evaporitic and Cavernous

712 HSUs and divert water to seeps and springs. All of these Upper GRL units; however, likely

713 transmit water laterally and the two Upper GRL confining units may; therefore, be better

714 described as “semi-confining HSUs”.

715 Analysis of fluid pathways is further complicated by the solution enhancement of

716 ichnofossils by meteoric water. Solution enhancement features are most significant in close

717 proximity to faults and fractures and within the GRL, the Upper GRL displays more solution

718 enhancement due to the high infiltration rates of the overlying Edwards aquifer (Maclay, 1995;

719 Smith et al., 2003; Clark, 2004). Solution enhancement greatly increases lateral and vertical

720 connectivity and permeability of units and, in some beds, was the first step toward development

721 of larger-scale karstic features.

722

Ichnofabric assessment of karstic aquifers may also be of benefit to hydrocarbon

723 exploration. Large-scale vug porosity is a common feature in karstic reservoirs and aquifers and

724 may have been mediated by biologic activity (Mazzullo and Chilingarian, 1996;Gingras et al.,

725 1999; Cunningham et al., 2009; Baniak et al., 2013). Understanding the interaction of burrows

726 and molds that may lead to such porosity may become increasingly important as part of reservoir

727 characterization. The shelf carbonates of south TX have been explored for oil and gas plays with

728 active fields targeting the Edwards Group and Austin Chalk Formation (Loucks, 1977). The

729 shallow marine carbonates of the GRL from south of the study have documented hydrocarbon

730 staining, but lacked significant structural or stratigraphic traps (Loucks, 1977). The hydrocarbon

731 stainingdemonstrates the potential of karstic systems to act as reservoirs and ichnologic

732 assessment may benefit such plays as the Edwards and Austin Chalk. This methodology may

733 also be expanded into other potential reservoirs such as the Ellenburger Group of western TX 
734 (Loucks, 1999) or the Arbuckle Group of Central Oklahoma (Kerans, 1988; Puckette et al., 735 2009).

736

737 Acknowledgments

738 The authors would like to recognize the landowners and managers of private and public 739 lands in Bandera, Blanco, Bexar, Comal, Hays, and Kendall counties who provided access to 740 their property for this study. We extend particular thanks to Ronald G. Fieseler, General 741 Manager of the Blanco-Pedernales Groundwater Conservation District for his efforts in 742 contacting various private land owners. We thank Stephen T. Hasiotis of the University of 743 Kansas for his assistance with ichnofossil identification for this project. We would like to thank 744 David V. Smith of the U.S. Geological Survey’s USGS Crustal Geophysics and Geochemistry 745 Science Center, for his supervision and leadership over the course of this project. We also thank 746 the Kansas Interdisciplinary Carbonates Consortium for funding portions of this research. 747 Finally, we thankboth of our reviewers for their insights that made this manuscript more 748 effective. 
765

766

\subsection{References}

Achauer, C.A., 1977, Contrasts in Cementation, Dissolution, and Porosity Development Between Two Lower Cretaceous Reefs of Texas, in Bebout, D.G., and Loucks, R.G., eds., Cretaceous carbonates of Texas and Mexico-Applications to subsurface exploration: Austin, University of Texas, Bureau of Economic Geology Report of Investigation 89, p. 127-137.

Adkins, W.S., 1928, Handbook of Texas Cretaceous Fossils: University of Texas Bulletin, no. 2838, 385 p.

Ashworth, J.B., 1983, Ground-water Availability of the Lower Cretaceous Formations in the Hill Country of South-central Texas: Texas Department of Water Resources Report 273, 172 p.

\section{Babcock, L.E., Merriam, D.F., West, R.R., 2000, Paleolimulus, an Early Limuline} (Xiphosurida), from Pennsylvanian-Permian Lagerstätten of Kansas and Taphonomic Comparison with Modern Limulus: Lethaia, vol. 33, p. 129-141.

Baniak, G.M., Gingras, M.K., and Pemberton, S.G., 2013, Reservoir Characterization of BurrowAssociated Dolomites in the Upper Devonian Wabamun Group, Pine Creek Gas Field, Central Alberta, Canada: Marine and Petroleum Geology, vol. 48, p. 275-292.

Barker, R.A., and Ardis, A.F., 1996, Hydrogeological Framework of the Edwards-Trinity Aquifer System, West-central Texas: U.S. Geological Survey Professional Paper 1421-B, 61 p. 
Barnes, V.E., 1981, Geologic Atlas of Texas, Llano Sheet: Austin, University of Texas: Austin, 775 Bureau of Economic Geology, 1 sheet, scale 1:250,000.

776

777 Barnes, V.E., 1965, Geology of the HaysQuadrangle, Blanco, Gillespie and Kendall Counties, 778 Texas: Austin, University of Texas-Austin, Bureau of Economic Geology, 1 sheet, scale $779 \quad 1: 24,000$.

780

781

782

Bebout, D.G., Schatzinger, R.A., and Loucks, R.G., 1977, Porosity distribution in the Stuart City Austin, Report of Investigations No. 89, p. 234-256.

785

786

Behrens, E.W., 1965, Environment Reconstruction for a Part of the Glen Rose Limestone, Central Texas: Sedimentology, vol. 4, p. 65-111.

788

789

Blome, C.D., and Clark, A.K., 2014, Key Subsurface Data Help to Refine Trinity Aquifer Hydrostratigraphic Units, South-central Texas: U.S. Geological Survey Data Series 768, 1 sheet, http://dx.doi.org/10.3133/ds768.

792

Blome, C.D., Faith, J.R., and Ozuna, G.B., 2007, Geohydrologic Framework of the Edwards and 794 Trinity Aquifers, South-Central Texas: U.S. Geological Survey Fact Sheet 2006-3145, 4 p. 
Braun, A.S., 2011, East to West Stratigraphic Cross Section, Northern Hays County: Surface to Subsurface Trinity Lithostratigraphy: in Implications for Groundwater Availability in the Hill Country, Eastern Blanco and Northern Hays Counties, Texas: Austin Geological Society, Guidebook 33.

Bromley, R.G., and Ekdale, A.A., 1986, Composite ichnofabrics and tiering of burrows: Geological Magazine, vol. 123, p. 59-65.

Bromley R.G. and Frey R.W., 1974, Redescription of the Trace Fossil Gyrolithes and Taxonomic Evaluation of Thalassinoides, Ophiomorpha, and Spongeliomorpha: Bulletin of the Geological Society of Denmark, vol. 23, p. 312-335.

Bumgarner, J.R., Stanton, G.P., Teeple, A.P., Thomas, J,V., Houston, N,A., Payne, J.D., Musgrove, M., 2012, A Conceptual Model of the Hydrogeologic Framework, Geochemistry, and Groundwater-flow System of the Edwards-Trinity and Related Aquifers in the Pecos County Region, Texas: SGS Scientific Investigations Report: 2012-5124, 74 p.

Carew, J.L., 1967, Study of a Portion of the Lower Glen Rose Formation, Steiner Ranch, Texas, in Scott, A.J. ed., Carbonate Depositional Environments, Central Texas, term reports: Department of Geology, Geology 383K, University of Texas, Austin, Texas, p. 54-63. 
817 Choquette, P.W., and Pray, L.C., 1970, Geologic Nomenclature and Classification of Porosity in 818 Sedimentary Carbonates: American Association of Petroleum Geologists Bulletin, vol. 54, 819 no. 2, p. 207-250.

820

821 Clark, A.K., 2003, Geologic Framework and Hydrogeologic Features of the Glen Rose

822 Limestone, Camp Bullis Training Site, Bexar County, Texas: U.S. Geological Survey

823 Scientific Investigations Report 03-4081, 9 p., 1 pl., scale 1:24,000.

824

825 Clark, A.K., 2005, Geologic Framework and Hydrogeologic Characteristics of the Glen Rose 826 Limestone, Camp Stanley Storage Activity, Bexar County, Texas: U.S. Geological Survey 827 Scientific Investigations Map 2831, 1 pl., scale 1: 25,000.

828

829 Clark, A.K., Blome, C.D., and Morris, R.R., 2014, Geology and Hydrostratigraphy of Guadalupe 830 River State Park and Honey Creek State Natural Area, Kendall and Comal Counties, Texas: U.S. Geological Survey Scientific Investigations Map 3303, 8 p., 1 sheet, scale 1:24,000.

832

833 Clark, A.K., Golab, J.A., and Morris, R.R., 2016, Geologic Framework, Hydrostratigraphy, and 834 Ichnology of the Blanco, Payton, and Rough Hollow 7.5-minute Quadrangles, Blanco, Comal, 835 Hays, and Kendall Counties, Texas: U.S. Geological Survey Scientific Investigations Map 836 3363, 21 p., 1 sheet, scale 1:24,000.

837

838 Clark, A.K., and Morris, R.R., 2015, Geologic and Hydrostratigraphic map of the Anhalt, 839 Fischer, and Spring Branch 7.5-minute Quadrangles, Blanco, Comal, and Kendall Counties, 

$1: 50,000$.

Clark, A.R., Blome, C.D., and Faith, J.R., 2009, Map Showing Geology and Hydrostratigraphy Geological Survey Open-File Report 2009-1008.

846

847

Cleaves, A.W., 1977, Middle Glen Rose (Cretaceous) Facies Mosaic, Blanco and Hays Counties, 848 Texas, in Bebout, D.G., and Loucks, R.G., eds., Cretaceous carbonates of Texas and Mexico-Applications to subsurface exploration: Austin, University of Texas, Bureau of Economic Geology Report of Investigation 89, 168 p.

851

852 Collins, E.W., 1992a, Geologic Map of the Anhalt 7.5-minute Quadrangle, Comal, Blanco, and 853 Kendall Counties, Texas: The University of Texas at Austin, Bureau of Economic Geology Open-File Map OFM0095, 1 sheet, scale 1:24,000.

855

856 Collins, E.W., 1992b, Geologic Map of the Fischer 7.5-minute Quadrangle, Comal, Blanco, and 857 Kendall Counties, Texas: The University of Texas at Austin, Bureau of Economic Geology 858 Open-File Map OFM0030, 1 sheet, scale1:24,000.

859

860 Collins, E.W., 1992c, Geologic Map of the Spring Branch 7.5-minute Quadrangle, Comal, 861 Blanco, and Kendall Counties, Texas: The University of Texas at Austin, Bureau of 862 Economic Geology Open-File Map OFM0011, 1 sheet, scale 1:24,000. 
864 Collins, E.W., 1995, Structural Framework of the Edwards Aquifer, Balcones Fault Zone,

865 Central Texas: Gulf Coast Association of Geological Societies, Transactions, vol. 38, p. 135-

866141.

867

868 Conwy Valley Systems Ltd., 2011, PetrogLite Version 3.0 for MS Windows OS. Conway, $869 \quad$ United Kingdom.

870

871 Cunningham, K.J. and Sukop, M.C., 2011, Multiple Technologies Applied to Characterization of 872 the Porosity and Permeability of the Biscayne Aquifer, Florida: U.S. Geological Survey 873 Open-File Report 2011-1037, 8 p.

874

875 Cunningham, K.J. and Sukop, M.C., 2012, Megaporosity and Permeability of Thalassinoides876 Dominated Ichnofabrics in the Creataceous Karst-Carbonate Edwards-Trinity Aquifer 877 System, Texas: U.S. Geological Survey Open-File Report 2012-1021, 4 p.

878

879 Cunningham, K.J., Sukop, M.C., Huang, H., Alvarez, P.F., Curran, H.A., Renken, R.A., and 880 Dixon, J.F., 2009, Prominence of Ichnologically Influenced Macroporosity in the Karst 881 Biscayne aquifer: Stratiform “super-K” zones, Geological Society of America Bulletin, vol. 882 121, no. 1/2; p. 164-180.

883

884 Droser, M.J. and Bottjer, D.J., 1986, A Semiquantitative Field Classification of Ichnofabric: 885 Journal of Sedimentary Petrology, vol. 56, no. 4, p. 558-559. 
887 Dunham, R.J., 1962, Classification of Carbonate Rocks According to Depositional Textures: in 888 American Association of Petroleum Geologists Memoir 1: Classification of Carbonate $889 \quad$ Rocks-A Symposium, p. 108-121.

890

891 Ekdale, A.A. and Bromley, R.G., 1984a, Comparative Ichnology of Shelf-Sea and Deep-Sea 892 Chalk: Journal of Paleontology, vol. 58, p. 322-332.

Ekdale, A.A. and Bromley, R.G., 1984b, Sedimentology and Ichnology of the Cretaceous895 896 Tertiary Boundary in Denmark: Implications for the Causes of the Terminal Cretaceous Extinction: Journal of Sedimentary Petrology, vol. 54, p. 681-703.

897

Embry, A.F. and Klovin, J.E., 1971, A Late Devionian Reef Bank on Northeastern Banks Island, 899 N.W.T.: Bulletin of Canadian Petroleum Geology, vol. 19, no. 4, p. 730-781.

900

901 Faith, J.R., 2004, Strain and Fractures in an Extensional Relay Ramp, Sierra del Carmen, Black 902 Gap Wildlife Management Area, Brewster County, Texas-Implications for Determining 903 Structural Controls on Groundwater Flow Pathways in the Edwards Aquifer, South-central 904 Texas: University of Texas at San Antonio, M.S. thesis, 88 p.

905

906 Fisher, W.L. and Rodda, P.U., 1969, Edwards Formation (Lower Cretaceous), Texas:

907 Dolomitization in a Carbonate Platform System: American Association of Petroleum 908 Geologists Bulletin, vol. 55, no. 1, p. 55-72. 
910 Gary, M.O., Rucker, D.F., Smith, B.D., Smith, D.V., and Befus, K., 2013, Geophysical

911 Investigations of the Edwards-Trinity Aquifer System at Multiple Scales: Interpreting

912 Airborne and Direct-Current Resistivity in Karst: NCKRI Symposium 2, 13th Sinkhole

913 Conference, p. 195-206.

914

915 George, W.O., 1952, Geology and Ground-water Resources of Comal County, Texas: U.S.

916 Geological survey Water-Supply Paper 1138, 126 p.

917

918 Gingras, M.K., Baniak, G., Gordon, J., Hovikoski, J., Konhauser, K.O., LaCroix, A.D., Lemiski,

919 R., Mendoza, C., Pemberton, S.G., Polo, C., and Zonneveld, J., 2012, Porosity and

920 Permeability in Bioturbated Sediments: Developments in Sedimentology, vol. 64, p. 837-

921868.

922

923 Gingras, M.K., Pemberton, S.G., Mendoza, C.A., and Henk, F., 1999, Assessing the Anisotropic

924 Permeability of Glossifungites Surfaces: Petroleum Geoscience, vol. 5, p. 349-357.

925

926 Gingras, M.K., Mendoza, C.A., and Pemberton, S.G., 2004, Fossilized Worm Burrows Influence

927 the Reservoir Quality of Porous Media: American Association of Petroleum Geologists

928 Bulletin, vol. 88, no. 7, p. 875-883.

929 
Golab, J.A., Clark, A.K., and Hasiotis, S.T., 2015, Bioturbation-Influenced Fluid Pathways within a Carbonate Platform System: The Aptian-Albian Glen Rose Limestone: GSA Annual Meeting, Baltimore, MD, 1-4 November.

Grimshaw, T. W., and Woodruff Jr., C.M., 1986, Structural Style in an En EchelonFault System, Balcones Fault Zone, Central Texas: Geomorphologic and Hydrologic Implications, in Abbott, P. L. and Woodruff, Jr., C.M., eds., The Balcones Escarpment—Geology, Hydrology, Ecology and Social Development in Central Texas: Guidebook published for the 1986 Geological Society of America Annual Meeting, San Antonio, Texas, p. 71-75.

Hanson, J.A., and Small, T.A., 1995, Geologic Framework and Hydrogeologic Characteristics of the Edwards Aquifer Outcrop, Hays County, Texas: U.S. Geological Survey WaterResources Investigations Report 95-4265, 10 p.

Hasiotis, S.T. and Mitchell, C.E., 1993, A Comparison of Crayfish Burrow Morphologies: Triassic and Holocene Fossil, Paleo- and Neo-ichnological Evidence, and the Identification of Their Burrowing Signatures: Ichnos, vol. 2, p. 291-314.

Hasiotis, S.T. and Platt, B.R., 2012, Exploring the Sedimentary, Pedogenic, andHydrologic Factors that Control the Occurrenceand Role of Bioturbation in Soil Formation andHorizonation in Continental Deposits:An Integrative Approach: The Sedimentary Record, vol. 10, p.4-9. 
953 Horvorka, S.D., Dutton, A.R., Ruppel, S.C., and Yeh, J., 1994, Sedimentologic and Diagenetic

954 Controls on Aquifer Properties, Lower Cretaceous Edwards Carbonate Aquifer, Texas:

955 Implications for Aquifer Management: Transactions of the Gulf Coast Association of

956 Geological Societies, vol. 44, p. 277-284.

957

958 Hunt, B.B. and Smith, B.A., 2010, Spring 2009 Potentiometric Map of the Middle Trinity

959 Aquifer in Groundwater Management Area 9, Central Texas: Barton Springs/Edwards Aquifer

960 Conservation District Report of Investigations 2010-0501, 31 p.

961

962 Inden, R. F., 1974, Lithofacies and Depositional Model for a Trinity Cretaceous Sequence,

963 Central Texas: in Aspects of Trinity Geology: Geoscience and Man, vol. 8, p. 37-52.

964

965 Imlay, R.W., 1945, Subsurface Lower Cretaceous Formations of South Texas: American

966 Association of Petroleum GeologistsBulletin, vol. 29, p. 1416-1469.

967

968 Kerans, C., 1988, Karst-controlled Reservoir Heterogeneity in Ellenburger Group Carbonates of

969 West Texas: American Association of Petroleum Geologists Bulletin, vol. 72, no. 10, p.

$970 \quad 1160-1183$.

971

972 Keswani, A. D. and Pemberton, S. G., 2007, Applications of Ichnology in Exploration and

973 Exploitation of Mississippian Carbonate Reservoirs, Midale Beds, Weyburn Oilfield,

974 Saskatchewan. In Alberta, Canada, Canadian Society of Petroleum Geologists and Canadian

975 Society of Exploration Geophysicists Conference, p. 14-17. 
977 Kraus, M. J. and Hasiotis, S.T., 2006, Significance of Different Modes of Rhizolith Preservation 978 to Interpreting Paleoenvironmental and Paleohydrologic Settings: Examples from Paleogene

979 Paleosols, Bighorn Basin, Wyoming, U.S.A.: Journal of Sedimentary Research, vol. 76, no. 980 4,p. 633-646.

981

982 La Croix, A.D., Gingras, M.K., Dashtgard, S.E., and Pemberton, S.G., 2012, Computer

983 Modeling Bioturbation: The Creation of Porous and Permeable Fluid-Flow Pathways:

984 American Association of Petroleum GeologistsBulletin, vol. 96, no. 3, p. 545-556.

985

986 Loucks, R.G., 1977, Porosity Development and Distribution in Shoal-Water Carbonate

987 Complexes-Subsurface Pearsall Formation (Lower Cretaceous) South Texas, in Bebout,

988 D.G. and Loucks, R.G., eds., Cretaceous carbonates of Texas and Mexico-Applications to 989 subsurface exploration: University of Texas at Austin, Bureau of Economic Geology Report $990 \quad$ of Investigation 89, p. 97-126.

991

992 Loucks, R.G., 1999, Paleocave Carbonate Reservoirs: Origins, Burial-Depth Modifications, 993 Spatial Complexity, and Reservoir Implications: American Association of Petroleum 994 Geologists Bulletin, vol. 83, no. 11, p. 1795-1834.

995

996 Lozo, F.E., and Stricklin Jr., F.L., 1956, Stratigraphic Notes on the Outcrop Basal Cretaceous, 997 Central Texas: Gulf Coast Association of Geological Societies Transactions, vol. 6, p. 67-78. 998 
Mace, R.E., Chowdhury, A.H., Anaya, H., Way, S., 2000, Groundwater Availability of the Trinity Aquifer, Hill Country Area, Texas: Numerical Simulations through 2050: Texas Water Development Board Report 353, 117 p.

Maclay, R.W., 1989, Edwards Aquifer in the San Antonio Region: Its Hydrology and Management: South Texas Geological Society Bulletin, vol. 30, no. 4, p. 11-28.

Maclay, R.W., 1995, Geology and Hydrology of the Edwards Aquifer in the San Antonio Area, Texas: U.S. Geological Survey Water Resources Investigations Report 95-4186, 64 p.

Maclay, R.W., and Small, T.A., 1976, Progress Report on Geology of the Edwards Aquifer, San Antonio Area, Texas, and Preliminary Interpretation of Borehole Geophysical and Laboratory Data on Carbonate Rocks: U.S. Geological Survey Open-File Report 76-627, 65 p.

Maclay, R.W., and Small, T.A., 1986, Carbonate Geology and Hydrology of the Edwards Aquifer in the San Antonio Area, Texas: Texas Water Development Board, Report 296, p. 90.

Mancini, E.A. and Scott, R.W., 2006, Sequence Stratigraphy of Comanchean Cretaceous Outcrop Strata of Northeast and South-Central Texas: Implications for Enhanced Petroleum Exploration: Gulf Coast Association of Geological Societies Transactions, vol. 56, p. 539550. 
1023 Maxey, G.B., 1964, Hydrostratigraphic Units: Journal of Hydrology, vol. 2, p. 124-129.

1024

1025 Mazzullo, S.J. and Chilingarian, G.V., 1996, Hydrocarbon Reservoirs in Karsted Carbonate

1026 Rocks: Developments in Petroleum Science, vol. 44, no. 2, p. 797-865.

1027

1028 Mylroie, J.E. and Carew, J.L., 1990, The Flank Margin Model for Dissolution Cave

1029 Development in Carbonate Platforms: Earth Surface Processes and Landforms, vol. 15, p.

$1030 \quad 413-424$.

1031

1032 Myrow, P.M., 1995, Thalassinoides and the Enigma of Early Paleozoic Open-Framework

1033 Burrow Systems: PALAIOS, vol. 10, no. 1, p. 58-74.

1034

1035 Pantea, M.P., Blome, C.D., and Clark, A.K. 2014, Three-Dimensional Model of the

1036 Hydrostratigraphy and Structure in and around the U.S. Army-Camp Stanley Storage

1037 Activity Area, Northern Bexar County, Texas: USGS Scientific Investigations Report 201410385074.

1039

1040 Pantea, M.P., Cole, J.C., Smith, B.D., Faith, J.R., and Blome, C.D., 2008, Three-Dimensional

1041 Geologic Model of Complex Fault Structures in the Upper Seco Creek Area, Medina and

1042 Uvalde Counties, South-Central Texas: U.S. Geological Survey Scientific Investigations

1043 Report 2008-5131, DVD-ROM, 9 p.

1044 
1045 Pemberton, S.G. and Frey, R.W., 1982, Trace Fossil Nomenclature and the Planolites-

1046 Palaeophycus Dilemma: Journal of Paleontology, vol. 56, no. 4, p. 843-881.

1047

1048 Perkins, B.F., 1974, Paleoecology of a Rudist Reef Complex in the Comanche Cretaceous, Glen

1049 Rose Limestone, Central Texas, in Perkins, B.F., ed., Aspects of Trinity Division Geology-

1050 A Symposium: Louisiana State University: Geoscience and Man, vol. 8, p. 131-173.

1051

1052 Petta, T.J., 1977, Diagenesis and geochemistry of a Glen Rose patch reef complex, Bandera

1053 County, Texas, in Bebout, D.G., and Loucks, R.G., eds., Cretaceous carbonates of Texas and

1054 Mexico-Applications to subsurface exploration: University of Texas at Austin, Bureau of

1055 Economic Geology Report of Investigation 89, p. 138-165.

1056

1057 Pittman, J.G., 1989, Stratigraphy of the Glen Rose Formation, Western Gulf Coast Plain: Gulf

1058 Coast Associations of Geological Societies Transactions, vol. 39, p. 247-264.

1059

1060 Puckette, J., Halihan, T., and Faith, J.R., 2009, Characterization of the Arbuckle-Simpson

1061 Aquifer-Final Report for the Arbuckle-Simpson Hydrology Study: Sillwater, Oklahoma,

1062 Oklahoma State University, School of Geology, for theOklahoma Water Resources Board, 53

1063 p.

1064

1065 Riding, R., 2007, Girvanella and Other Algae as Depth Indicators: Lethaia, vol. 8, p. 173-179.

1066 
1067 von Roemer, C.F., 1852, Die Kreidebildungen von Texas und Ihre Organischen Einschliisse:

1068 Bonn, p. 1-10.

1069

1070 Rose, P.R., 1972, Edwards Group, Surface and Subsurface, Central Texas: University of Texas at 1071 Austin, Bureau of Economic Geology Report of Investigations 74, 198 p.

1072

1073 Schlager,W., 1989, Drowning Unconformities on Carbonate Platforms: Controls on Carbonate 1074 Platform and Basin Development, SEPM Special Publication No. 44, p. 15-25.

1075

1076 Scanlon, B.R., Mace, R.E., Barrett, M.E., and Smith, B., 2003, Can We Simulate Regional 1077 Groundwater Flow in a Karst System Using Equivalent Porous Media Models? Case study, 1078 Barton Springs Edwards aquifer, USA: Journal of Hydrology, vol. 276, p.137-158.

1079

1080 Scott, R.W., Molineux, A.M., and Mancini, E.A., 2007, Lower Albian Sequence Stratigraphy 1081 and Coral Buildups-Glen Rose Formation, Texas, USA, in Scott, R.W., ed., Cretaceous

1082 Rudists and Carbonate Platforms_Environmental feedback: Society for Sedimentary 1083 Geology, v. 87, p. 181-191.

1084

1085 Sheehan, P.M. and Schiefelbein, D.R.J., 1984, The Trace Fossil Thalassinoides from the Upper 1086 Ordovician of the Eastern Great Basin: Deep Burrowing in the Early Paleozoic: Journal of 1087 Paleontology, vol. 58, no. 2, p. 440-447. 
1089 Small, T.A. and Lambert, R.B., 1998, Geologic Framework and Hydrogeologic Characteristics

1090 of the Outcrops of the Edwards and Trinity Aquifers, Medina Lake Area, Texas: U.S.

1091 Geological Survey Water-Resources Investigations Report 97-4290, 21 p.

1092

1093 Smith, B.D., Cain, M.J., Clark, A.K., Moore, D.W., Faith, J.R., Hill, P.R., 2005, Helicopter

1094 Electromagnetic and Magnetic Survey Data and Maps, Northern Bexar County, Texas: U.S.

1095 Geological Survey Open-File Report 05-1158, 24 p.

1096

1097 Smith, J.J., Hasiotis, S.T., Kraus, M.J., and Woody, D.T., 2008, Relationship of Floodplain

1098 Ichnocoenoses to Paleopedology, Paleohydrology, and Paleoclimate in the Willwood

1099 Formation, Wyoming, During the Paleocene-Eocene Thermal Maximum: PALAIOS, vol.

$1100 \quad$ 23, p. 683-699.

1101

1102 Stricklin, F. L. and Amsbury, D.L., 1974, Depositional Environments on a Low-Relief Carbonate

1103 Shelf, Middle Glen Rose limestone, Central Texas: Geoscience and Man, vol. 8, p. 53-66.

1104

1105 Stricklin, F.L., Jr., Smith, C.I., and Lozo, F.E., 1971, Stratigraphy of Lower Cretaceous Trinity

1106 Deposits of Central Texas: University of Texas at Austin, Bureau of Economic Geology

1107 Report of Investigations 71, 63 p.

1108

1109 Tonkin, N.S., McIlroy, D., Meyer, R., and Moore-Turpin, A., 2010, Bioturbation Influence on

1110 Reservoir Quality: A Case Study from the Cretaceous Ben Nevis Formation, Jeanne d’Arc 
1111 Basin, Offshore Newfoundland, Canada: American Association of Petroleum

1112 GeologistsBulletin, vol. 94, p. 1059-1078.

1113

1114 Uchman, A., 1995, Taxonomy and Palaeoecology of Flysch Trace Fossils: The Marnosoarenacea

1115 Formation and Associated Facies (Miocene, Northern Apennines, Italy): Beringeria, vol. 15, 1116 p. 3.

1117

1118 Uchman, A., 1998, Taxonomy and Ethology of Flysch Trace Fossils: ARevision of the Marian-

1119 Książkiewicz Collection and Studies of Complementary Material: Annales Societatis

1120 Geologorum Poloniae, vol. 68, p. 105-218.

1121

1122 Vinn, O., Hove, H.A.T., Mutvei, H., and Kirsimäe, K., 2008, Ultrastructure and Mineral

1123 Composition of Serpulid Tubes (Polychaeta, Annelida): Zoological Journal of the Linnean

1124 Society, vol. 154, p. 633-650.

1125

1126 Ward, W.C. and Ward, B.W., 2007, Stratigraphy of Middle Part of the Glen Rose Formation

1127 (Lower Albian), Canyon Lake Gorge, Central Texas, U.S.A.: Cretaceous Rudists and

1128 Carbonate Platforms: Environmental Feedback: SEPM Special Publication 87, p. 193-210.

1129

1130 Wentworth, C.K., 1922, A Scale of Grade and Class Terms for Clastic Sediments: Journal of

1131 Geology, vol. 31, p. 377-392.

1132 
1133 Whitney, M.I., 1952, Some Zone Marker Fossils of the Glen Rose Formation of Central Texas:

1134 Journal of Paleontology, vol. 26, no. 1, p. 65-73.

1135

1136 Winter, J.A., 1961, Stratigraphy of the Lower Cretaceous (Subsurface) of South Texas: Gulf

1137 Coast Association of Geological Societies Transactions, vol. 11, p.15-24.

1138

1139 Winters, W.J., Dallimore, S.R., Collett, T.S., Katsube, T.J., Jenner, K.A., Cranston, R.E., Wright,

1140 J.F., Nixon, F.M., and Uchida, T., 1999, Physical Properties of Sediments from the

1141 JAPEX/JNOC/GSC Mallik 2L-38 Gas Hydrate Research Well: in Dallimore, S.R., Uchida,

1142 T., and Collett, T.S., eds., Scientific Results from JAPEX/JNOC/GSC Mallik 2L-38 Gas

1143 Hydrate Research Well, Mackenzie Delta, Northwest Territories, Canada: Geological Survey

1144 of Canada Bulletin 544, p. 95-100.

1145

1146 Wright, V.P., Baceta, J.I., Lapointe, P.A., 2014, Paleokarstic Macroporosity Development at

1147 Platform Margins: Lessons from the Paleocene of North Spain: Interpretation, vol. 2, p. 1-16.

1148

1149 Zhou, W., Beck, B.F., Adams, A.L., 2002, Effective Electrode Array in Mapping Karst Hazards

1150 in Electrical Resistivity Tomography: Environmental Geology, vol. 42, p. 922-928.

1151 


\section{$1152 \quad$ 8.0 Captions}

1153 Figures

1154 Figure 1. Location map showing the regional extent of the Edwards and Trinity aquifer outcrop

1155 and subsurface catchment area as well as the extent of carbonate platform deposition in Texas.

1156 Locations of the Llano Uplift and Stuart City Reef, which affected GRL deposition, are also

1157 shown. Approximate locations of the four measured sections and two cores used in this study are

1158 indicated. Regional aquifer extent modified from Blome et al. (2007); extent of carbonate

1159 deposition and location of regional features modified from Pittman (1989).

1160

1161 Figure 2. Chart summarizing the lithostratigraphy, sequence stratigraphy, and hydrostratigraphy

1162 of the Trinity Group on the Central Texas Platform. Hosston and Sligo formations are found only

1163 in the subsurface within the study area. The Pearsall Formation and Glen Rose Limestone were

1164 examined in outcrop and core. The overlying Edwards Group is found in some outcrops within

1165 the study area. Ages of formations and members from Stricklin et al. (1971) and Clark and

1166 Morris (2015).

1167

1168 Figure 3. Lithofacies of the Glen Rose Limestone within the study area. A) Weathered outcrop

1169 section of nodular and massive marly fossiliferous wackestone-packstone. B) Roadcut section

1170 showing a detailed, unweathered face of nodular and massive marly fossiliferous wackestone-

1171 packstone. C) Outcrop of bedded and crossbedded argillaceousfossiliferous wackestone-

1172 packstone with low-angle crossbedding. D) Close-up photograph of bedded and crossbedded

1173 argillaceousfossiliferous wackestone-packstone showing low angle crossbedding. E) Outcrop of 
1174 well indurated, ledge-forming fossiliferous grainstone (arrow) with a sharp basal contact above a 1175 nodular, marly fossiliferous wackestone-packstone.

1177 Figure 4. Lithofacies of the Glen Rose Limestone within the study area(continued). A)

1178 Weathered outcrop of boxwork gypsum and mudstone within evaporitic mudstone facies. B)

1179 Symmetrical ripples in Corbula packstone-grainstone facies. Top of bed shown in photograph is 1180 the contact between the Upper and Lower Glen Rose Limestone. C) Close-up photograph of 1181 Corbula packstone-grainstone facies showing detailed Eoursivivas harveyi shells. D) Caprinid 1182 sp. in life position within rudist-dominated bafflestone facies. E) Laminated calcareous mudstone 1183 in core MW6-LGR with convoluted laminae (arrows). F) Carbonate-cemented sandstone with 1184 brecciated limestone clasts (arrows).

1186 Figure 5. Ichnofossils of the Glen Rose Limestone within the study area. A)Thalassinoides 1187 network with packstone infill dominated by skeletal grains of the foraminfera Orbitolina texana. 1188 Matrix around the burrows has been weathered out following exposure, but was originally 1189 mudstone.B) Solution-enhanced Thalassinoides network with packstone infill within a 1190 wackestone matrix (arrows). Packstone infill is fossiliferous and similar to overlying 1191 wackestone-packstone strata. C) Thalassinoides network with solution-enhanced open burrows 1192 throughout the strata. D) Palaeophycuswith packstone infill and a distinct, brown-tan oxidized 1193 mud lining. Found in association with Thalassinoides networks. E) Planolites with distinct, light1194 colored mudstone infill oriented parallel to bedding surface within a wackstone matrix. F) 1195 Planolites with distinct, light-colored mudstone infill (arrow) within a conglomeratic matrix 1196 containing detrital clasts. 
1198 Figure 6. Ichnofossils of the Glen Rose Limestone within the study area. A) Ophiomorpha within 1199 a packstone matrix with similar packstone infill. Pellets are visible around the burrow (arrow) B) 1200 Ophiomorphawith branching networks and weathered-out matrix due to subaerial exposure. 1201 C)Serpulid tube on a bivalve shell showing typical coiled morphology. D) Thin-section 1202 pictomicrograph of a serpulid tube from core MW9-CC showing cement coating and laminated 1203 mud infill. Growth of sparry cement acts as a geopetal (arrow). E) Rhizolith and rhizohalo within 1204 a highly bioturbated (ii5) marly wacketone. F) Spherical rhizocretions formed around roots and 1205 root hairs indicating abundant plant growth during subaerial exposure (arrows). G) Cruziana 1206 oriented along a bedding surface and indicating firmground-hardground conditions. This 1207 Cruziana is $\sim 13.0 \mathrm{~cm}$ wide and $\sim 59.3 \mathrm{~cm}$ long; lens cap is $5.7 \mathrm{~cm}$ in diameter.

1209 Figure 7. Model of ichnofabric index (ii) progression in Thalassinoides-dominated Glen Rose 1210 Limestone strata based on the scheme of Droser and Bottjer (1986). A) Top shows a single bed 1211 with ii2 and Palaeophycus and bottom shows the development of an untiered Thalassinoides 1212 network with ii3. B) Bed with ii4 and interconnectedThalassinoides network. C) Further 1213 development of a tiered Thalassinoides network over time leading to ii5 and nodular bedding. D)

1214 Further development of Thalassinoides networks leading to completely homogenized sediment 1215 with ii6.

1217 Figure 8. Chart showing overall dataset for the Glen Rose Limestone within the study area 1218 including: composite stratigraphic section, porosity and permeability data from He-expansion 1219 testing, matrix porosity from point counted data. Hydrostratigraphic units are designated as either 
1220 transmissive (T) or confining (C) according to Clark (2003) and Clark and Morris (2015).

1221 Porosity and permeability data from He-expansion testing in Lower Glen Rose Limestone core

1222 MW5-LGR modified from Blome and Clark (2014). Uppermost Cavernous hydrostratigraphic

1223 unit not shown on column as it is not present in outcrop within the study area.

1224

1225 Figure 9. Stratigraphic column from the Lower Glen Rose Limestone (GRL) Honey Creek

1226 hydrostratigraphic unit in Hays County, Texas showing the typical coarsening-upward

1227 successions and ichnofabric index (ii) patterns seen in Lower GRL transmissive units.

1228 Interpretations of fluid-flow characteristics shown under Hydrostratigraphy.

1230 Figure 10. Stratigraphic column from the Lower Glen Rose Limestone (GRL) Twin Sisters

1231 hydrostratigraphic unit from core in northern Blanco County, Texas showing the typical marly

1232 sedimentation and ichnofabric index (ii) patterns seen in Lower GRL confining units.

1233 Interpretations of fluid-flow characteristics shownunder Hydrostratigraphy.

1235 Figure 11. Stratigraphic column from the Upper Glen Rose Limestone (GRL) Camp Bullis

1236 hydrostratigraphic unit (HSU) in Kendall County, Texas showing the typical coarsening-upward

1237 successions and ichnofabric index (ii) patterns seen in Upper GRL confining units. These units

1238 have been described in this report as "semi-confining”.Interpretations of fluid-flow

1239 characteristics shownunder Hydrostratigraphy.

1241 Figure 12. Diagram showing the progression of solution enhancement within the GRL. $T_{1}$ ) The 1242 initial condition of coarse-grained infilled Thalassinoides (Th) and Palaeophycus (Pa). $\mathrm{T}_{2}$ ) 
1243 Introduction of meteoric water begins to dissolve the matrix surrounding the burrows and 1244 dissolve infill. $\mathrm{T}_{3}$ ) Dissolution of matrix material interconnects burrow networks across the 1245 three-dimensional extent of the bed. $\mathrm{T}_{4 \mathrm{a}}$ ) Solution-enhanced burrow networks filled with 1246 sediment being moved by groundwater flow and cemented. $\mathrm{T}_{4 \mathrm{~b}}$ ) Cemented, solution-enhanced 1247 burrows weather differentially from the surrounding matrix and are preserved in positive relief. $1248 \mathrm{~T}_{5 \mathrm{~b}}$ ) Continued dissolution of matrix surrounding burrows from meteoric water thins rock 1249 between networks. $\mathrm{T}_{5 \mathrm{~b}}$ ) Weight of overburden collapses strata and creates a brecciated bed. 1250

1251 


\section{Lithofacies Lithofacies Name}

\section{Code}

Nwp

Cwp

Fossiliferous grainstone (Fig. 3E)

Cross-bedded

argillaceous

wackestone-packstone

(Figs. 3C-D)

\section{Lithology and Sedimentary Structures}

Gray-tan, wackestone-packstone containing mostly shell fragment clasts. Clasts include foraminiferans, gastropods, bivalves, mollusks, and echinoid shells. Few sedimentary structures present. Appears nodular in outcrop.

Gray, argillaceous wackestone-packstone containing whole and very fine- to medium-grained fragmentary shell clasts. Shells include gastropod, bivalve, mollusk, and echinoid shells. Contains low-angle trough crossbeds and some laminations. Iron staining and dendrites are common.

Gray-tan, grainstone consisting of shell fragments and submarine calcite cement. Clasts include gastropod, and echinoid shell fragments. Commonly massive, but some beds contain low-angle to trough crossbedding.

Dendrites and pervasive iron staining are common.

\section{Thickness Porosity \\ Ichnofossils}

0.1-1.8 m Fracture, moldic, and Thalassinoides, shelter. 8-35\% matrix Ophiomorpha, porosity.

Palaeophycus, Planolites, rhizoliths, Serpulid tubes

\section{2-0.4 m Biotutbation- Thalassinoides,} influenced, fracture, Ophiomorpha, moldic, shelter, fenestral, and interparticle. $8-23 \%$ Palaeophycus, Planolites, rhizoliths, Serpulid tubes, matrix porosity.

\section{Intergranular and fracture. $3-35 \%$} matrix porosity.

\section{None}

Fracture and moldic. Planolites $14-22 \%$ matrix porosity. bivalve, gastropod, and echinoid shell fragments and whole Orbitolina minuta . Little to no primary sedimentary structures. Commonly massive and convoluted. gypsum and anhydrite.Clasts rare, but contains some

Evaporitic mudstone (Fig. Gray-tan, carbonate mudstone with boxwork crystalline $<1 \mathrm{~m}$ 4A) 


\begin{tabular}{|c|c|c|c|c|}
\hline $\begin{array}{l}\text { Hydrostratigraphic } \\
\text { Unit }\end{array}$ & Lithofacies & Ichnofossils & Transimissivity & $\begin{array}{l}\text { Bioturbation } \\
\text { influenced }\end{array}$ \\
\hline Cavernous & Nwp & Thalassinoides & Transmissive & High \\
\hline Camp Bullis & Nwp, Fgs, Lcm & $\begin{array}{l}\text { Thalassinoides, } \\
\text { Ophiomorpha, } \\
\text { Palaeophycus, } \\
\text { rhizoliths }\end{array}$ & Semi-confining & High \\
\hline Upper Evaporite & Ems & Planolities & Transmissive & Very low \\
\hline Fossiliferous & Nwp, Lcm, Rdf, Rdb & $\begin{array}{l}\text { Thalassinoides, } \\
\text { Ophiomorpha, } \\
\text { Palaeophycus, } \\
\text { rhizoliths, Serpulid } \\
\text { tubes }\end{array}$ & Semi-confining & High \\
\hline Lower Evaporite & Ems & Planolities & Transmissive & Very low \\
\hline Bulverde & $\begin{array}{l}\text { Nwp, Cwp, Cpg, } \\
\text { Lcm, Rdf, Rdb }\end{array}$ & $\begin{array}{l}\text { Thalassinoides, } \\
\text { Palaeophycus, } \\
\text { Planolites, } \\
\text { Cruziana, } \\
\text { rhizoliths }\end{array}$ & Semi-confining & Moderate \\
\hline Little Blanco & Nwp, Cwp, Rdf, Rdb & $\begin{array}{l}\text { Thalassinoides, } \\
\text { Palaeophycus, } \\
\text { Planolites, }\end{array}$ & Transmissive & High \\
\hline Twin Sisters & Nwp, Rdf, Rdb & Thalassinoides & Confining & Low \\
\hline Doeppenschmidt & Nwp, Lcm, Rdf, Rdb & $\begin{array}{l}\text { Thalassinoides, } \\
\text { Palaeophycus }\end{array}$ & Transmissive & High \\
\hline Rust & Nwp, Rdf, Rdb & $\begin{array}{l}\text { Thalassinoides, } \\
\text { Palaeophycus, } \\
\text { Planolites, }\end{array}$ & Confining & Low \\
\hline Honey Creek & $\begin{array}{l}\text { Nwp, Lcm, Rdf, } \\
\text { Rdb, Ccs }\end{array}$ & $\begin{array}{l}\text { Thalassinoides, } \\
\text { Palaeophycus, } \\
\text { Planolites }\end{array}$ & Transmissive & High \\
\hline
\end{tabular}




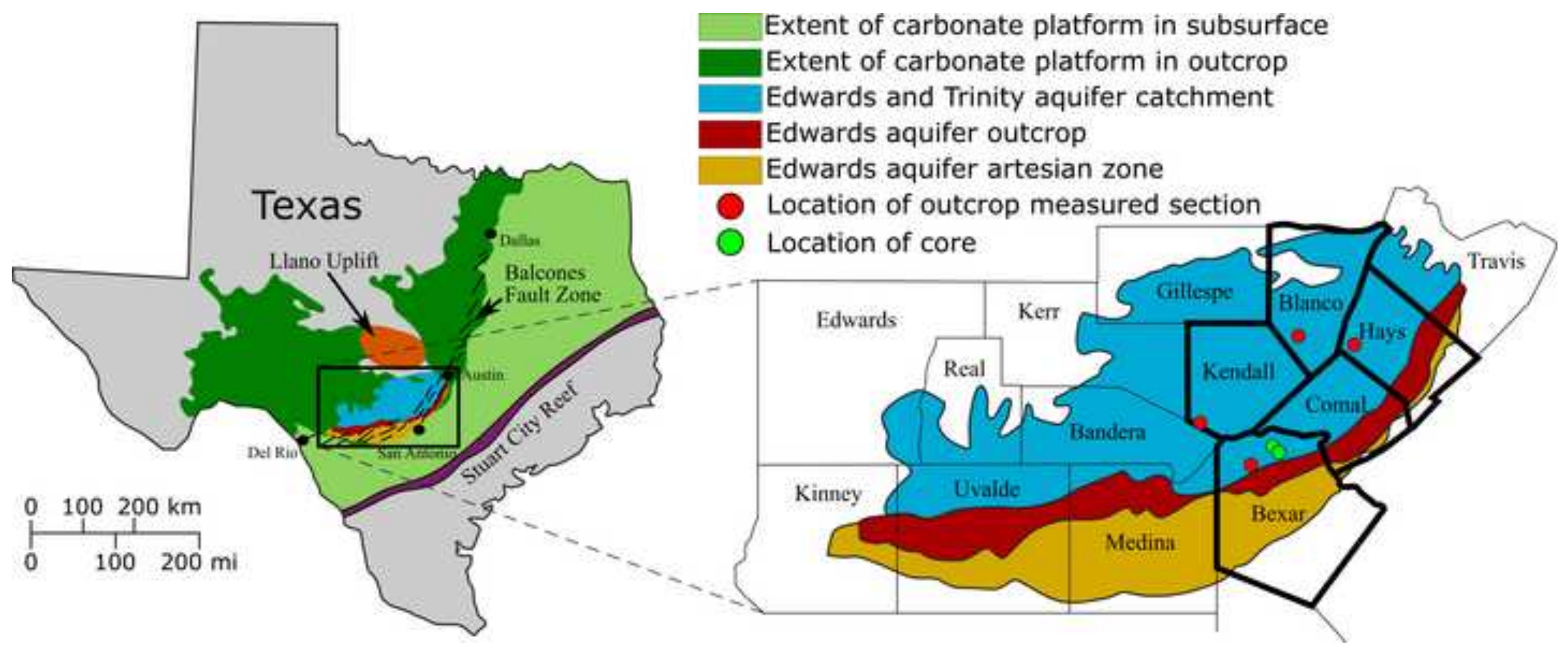




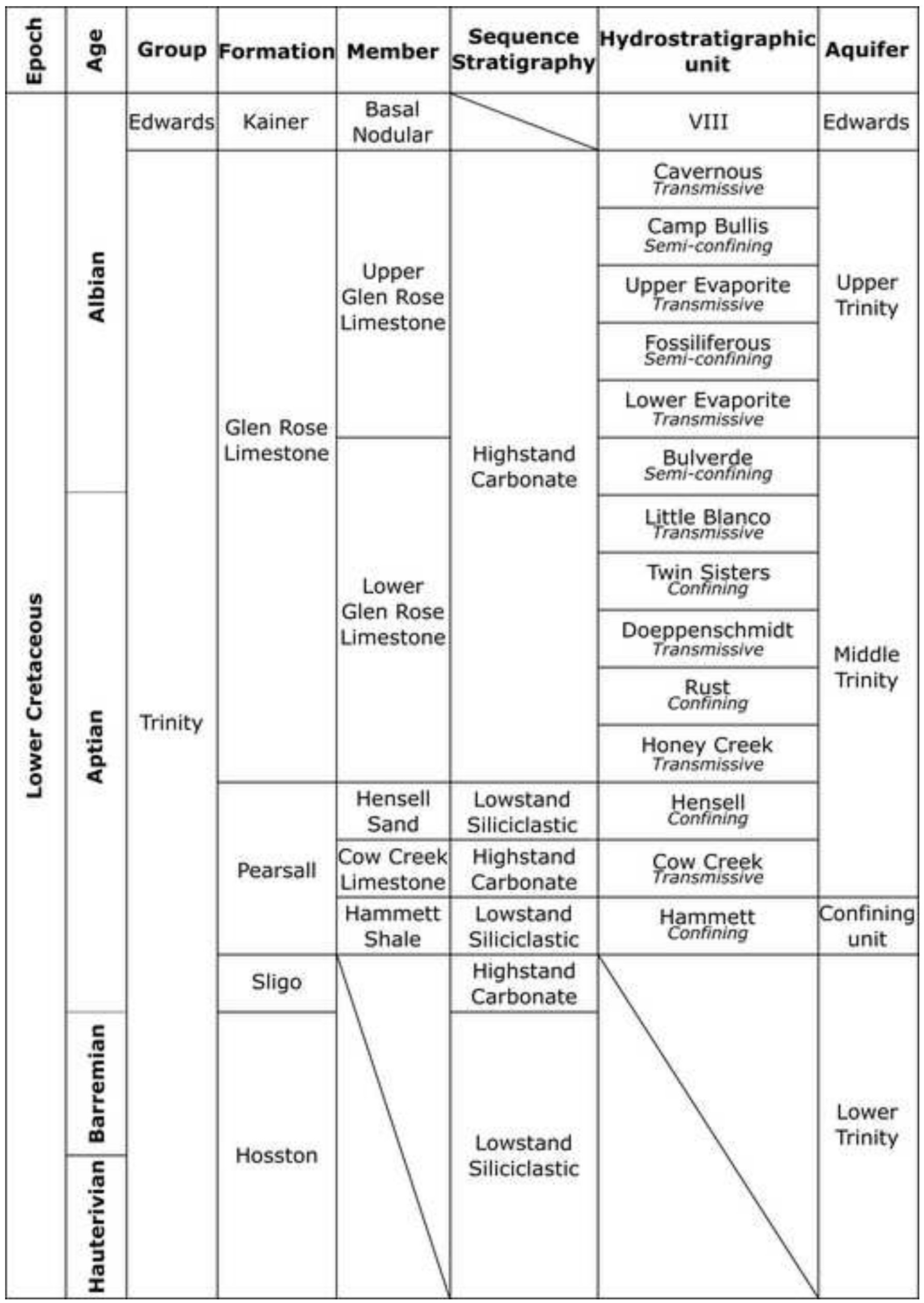



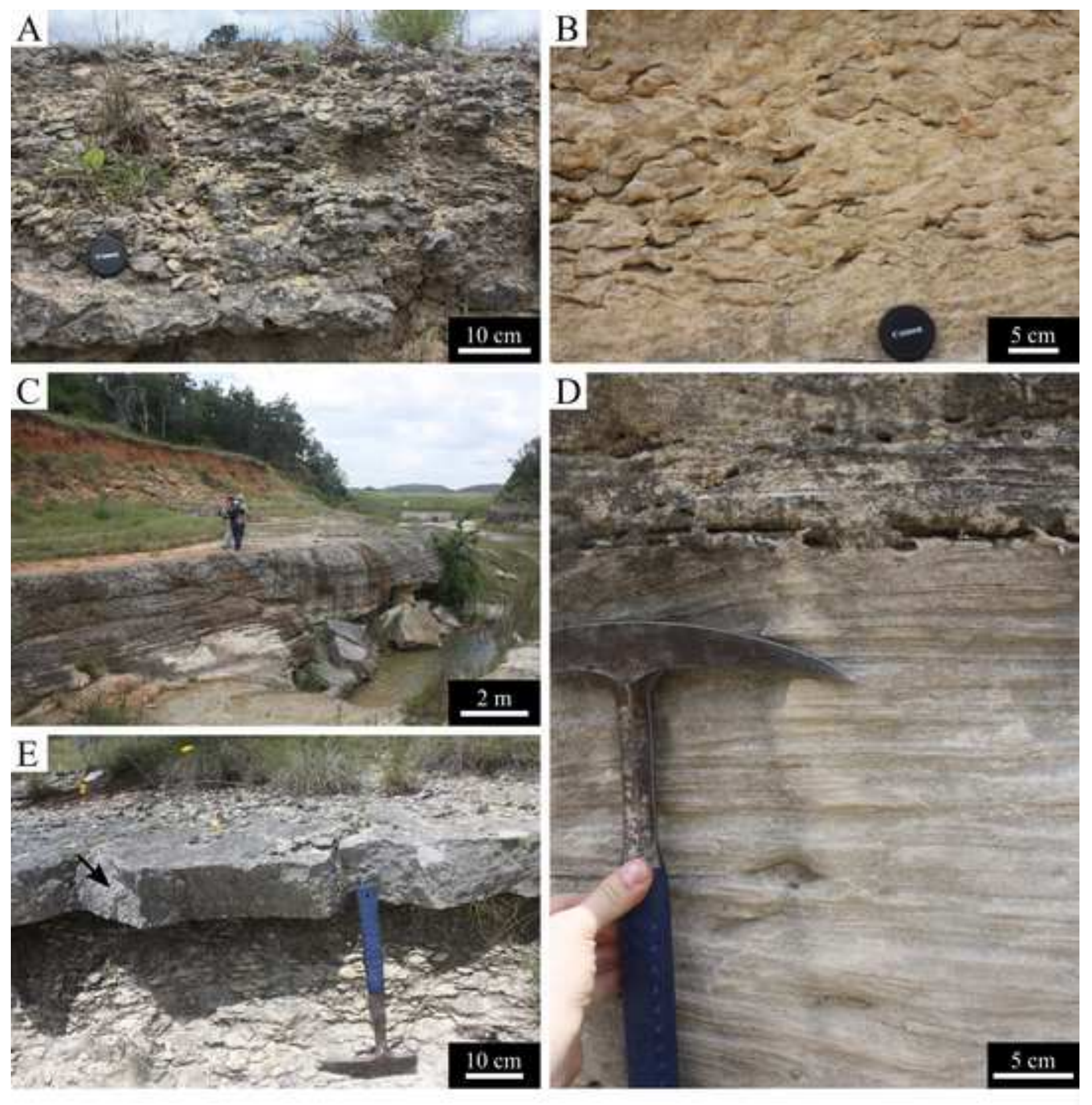

-
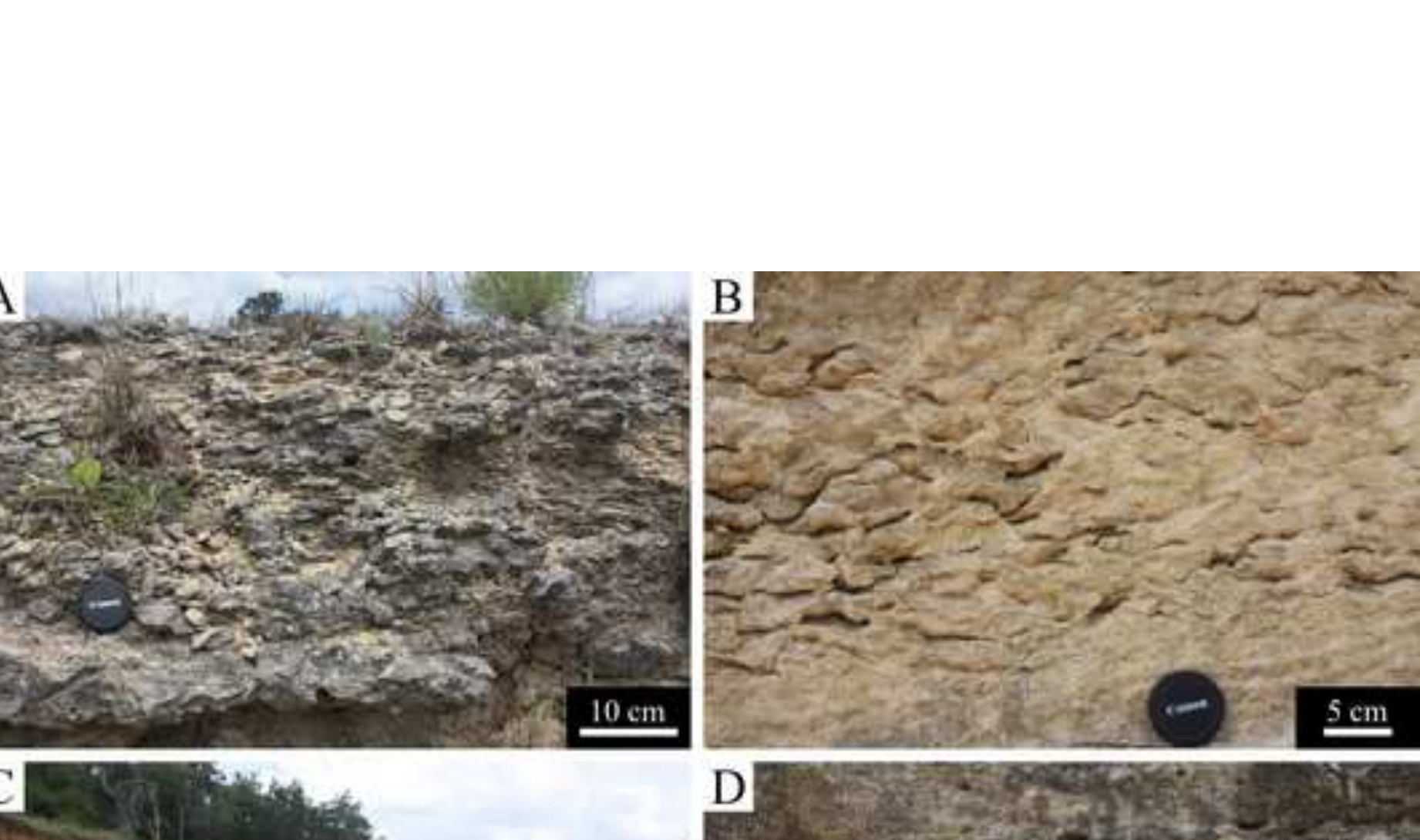

Figure 3 mas

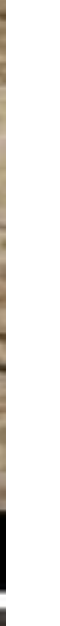

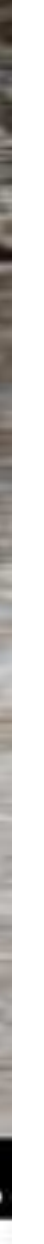



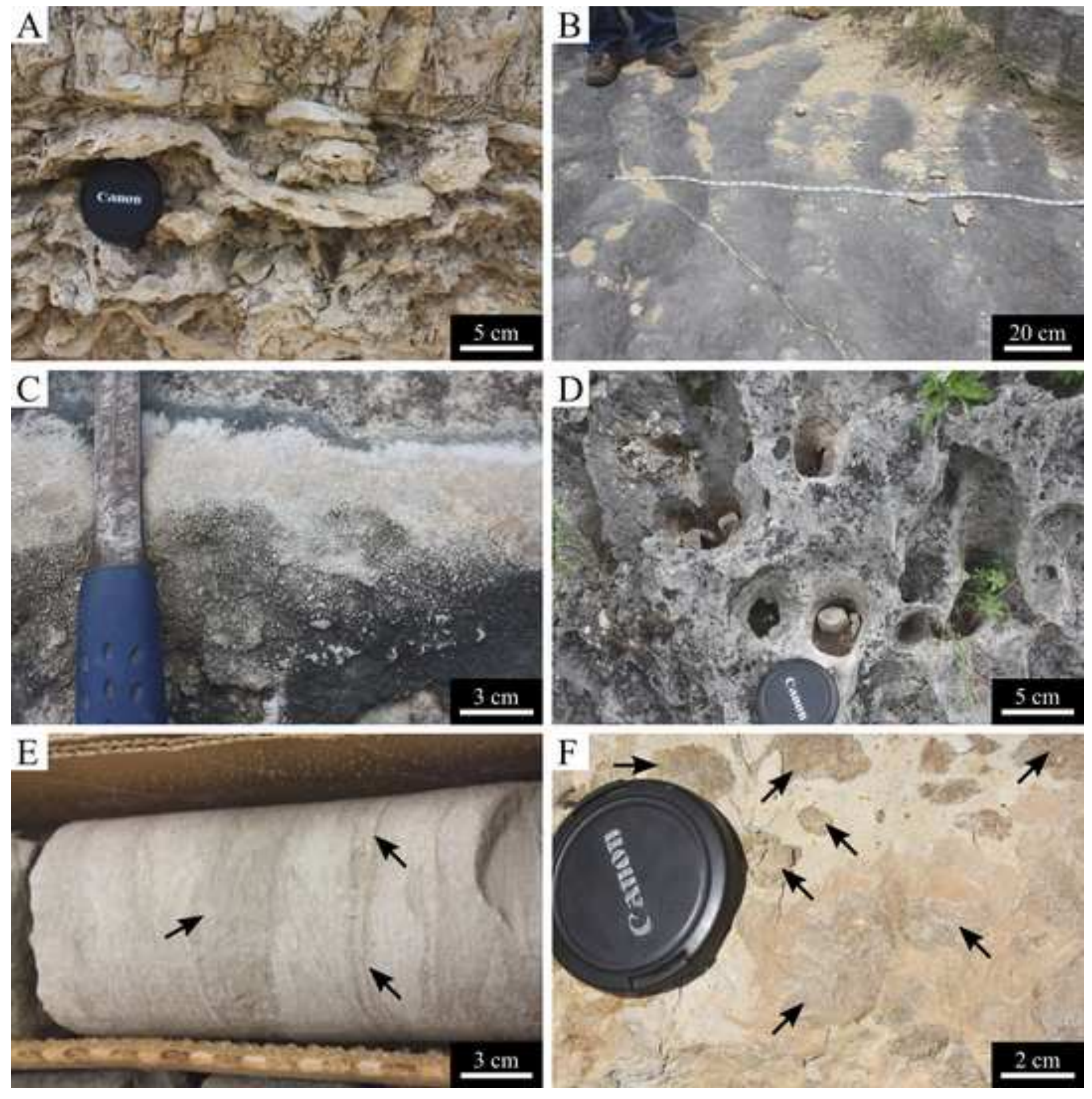

Figure 4 

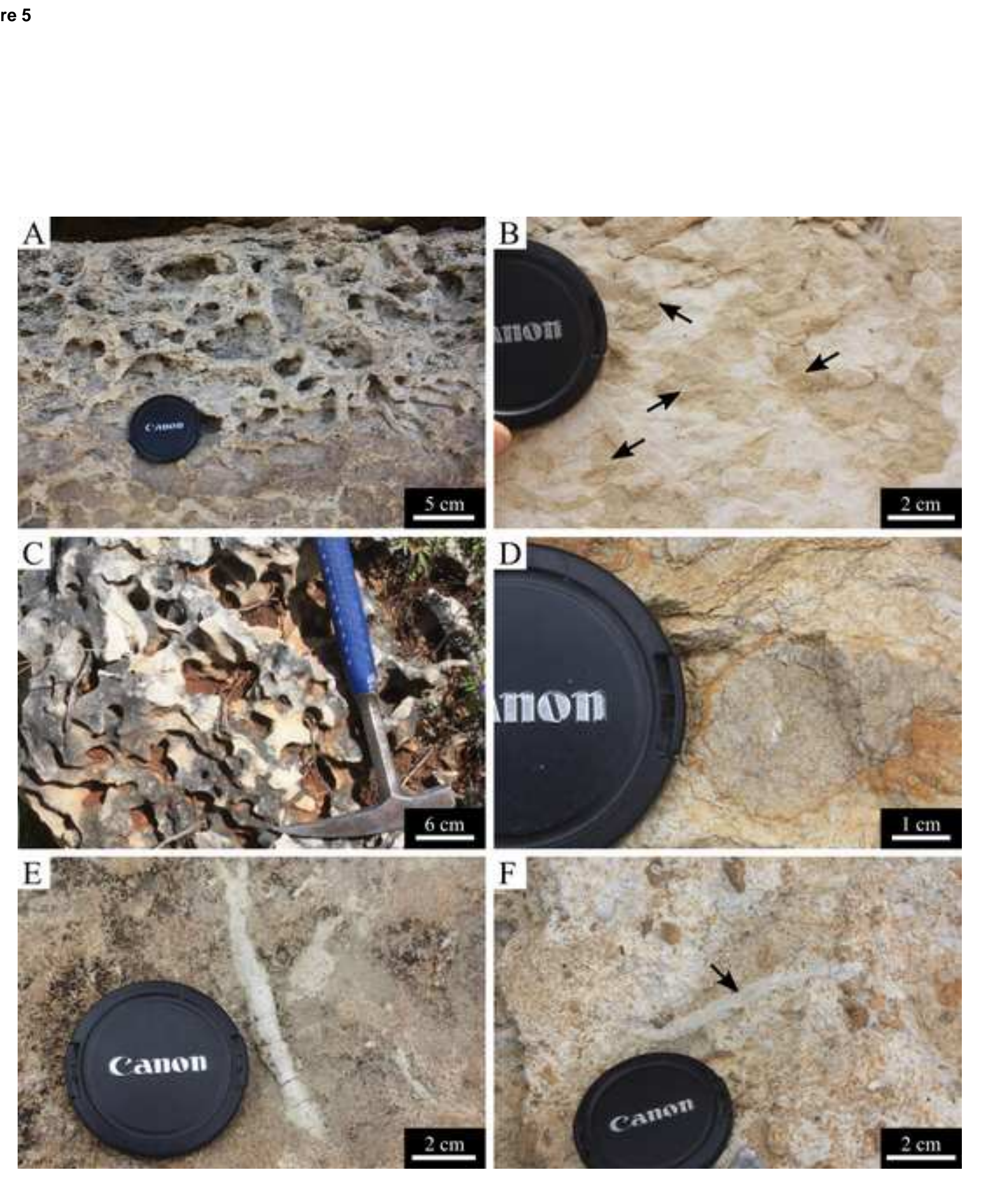

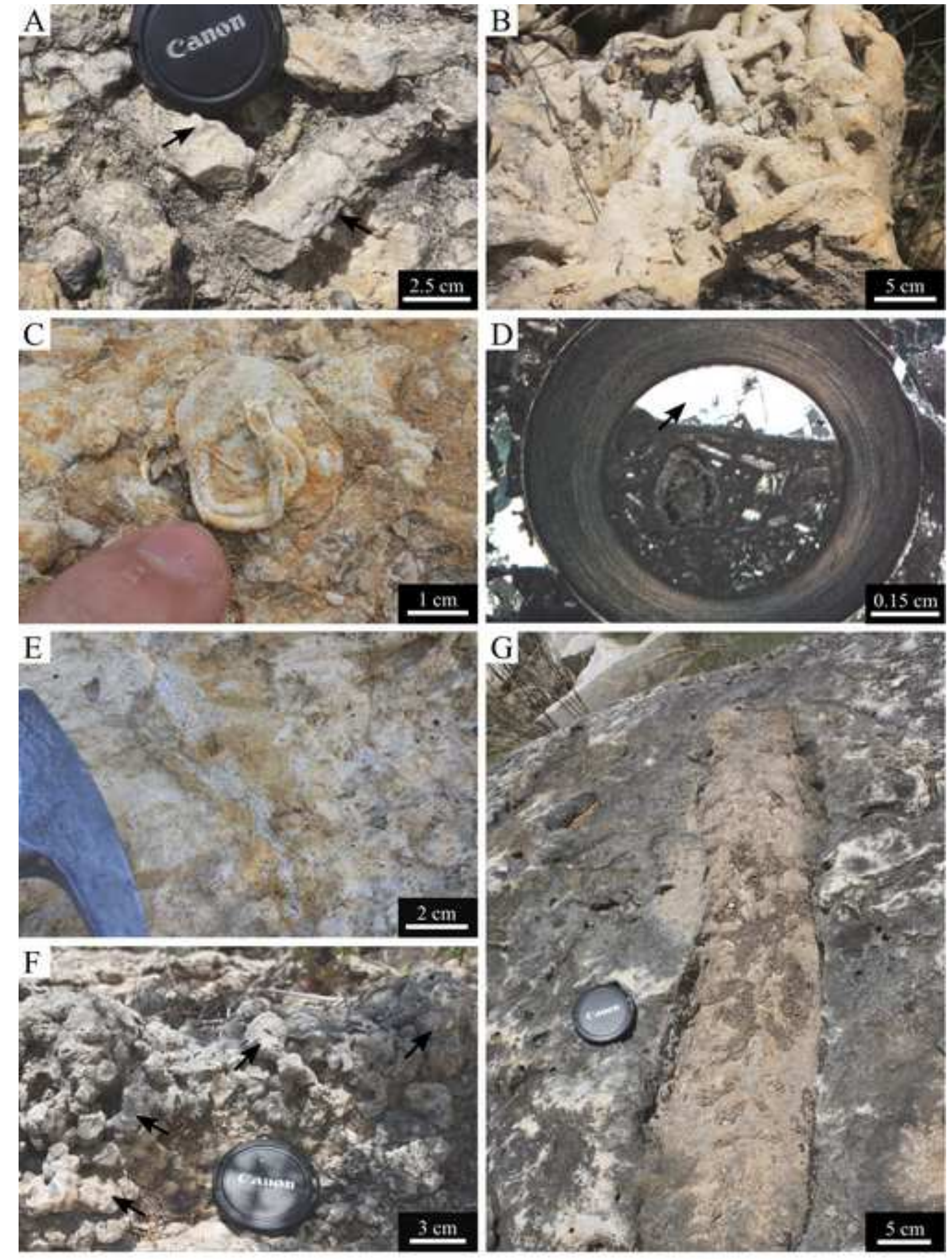
A
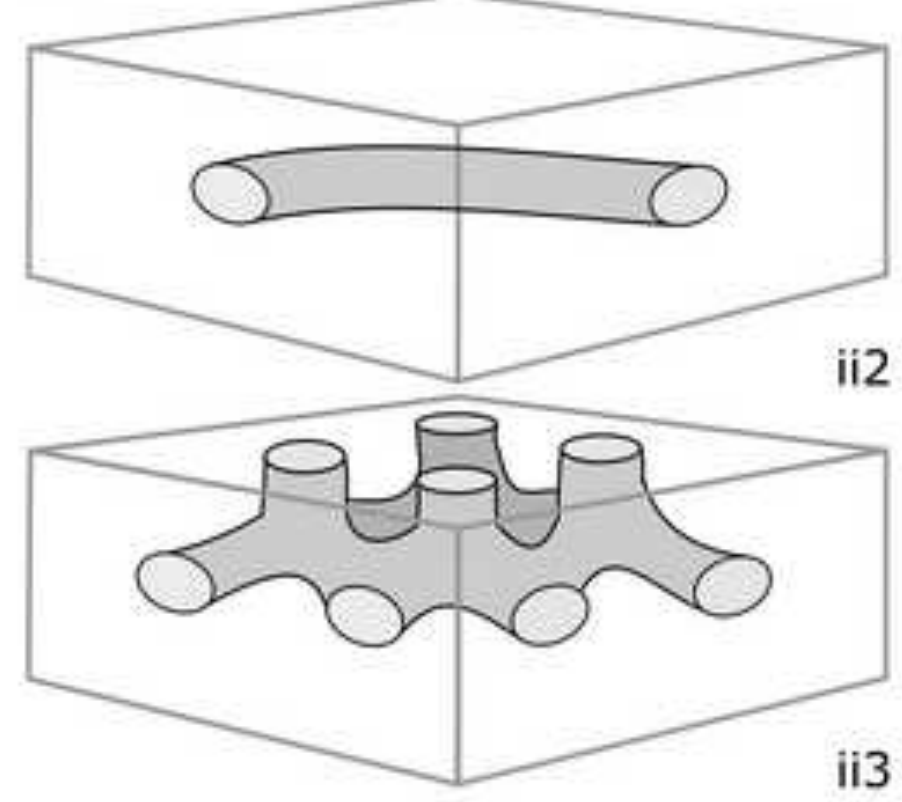

C

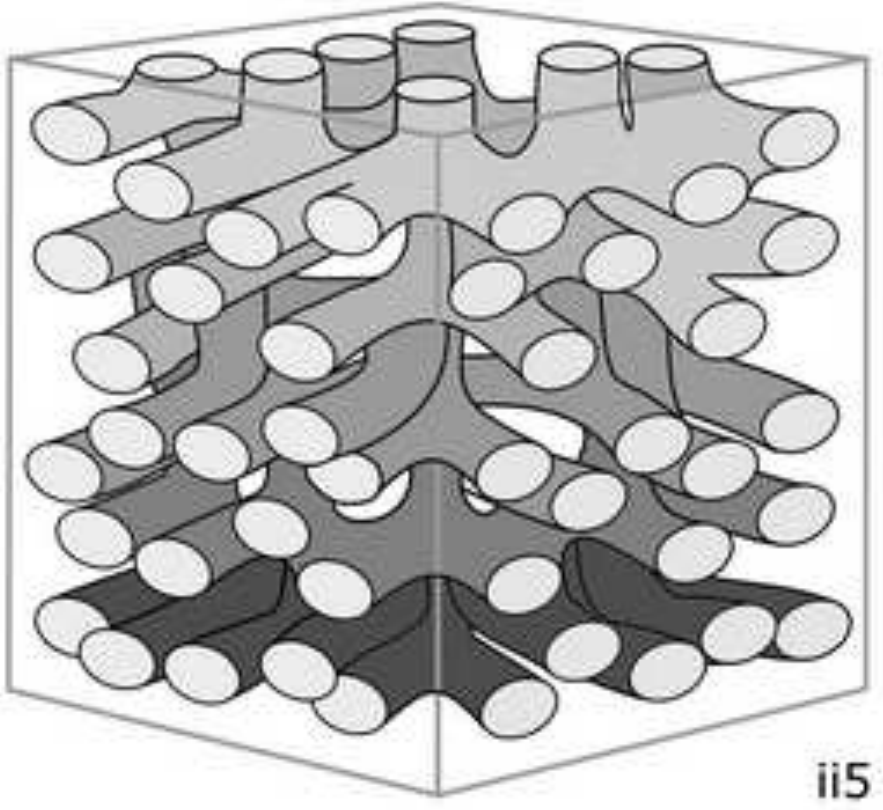

B

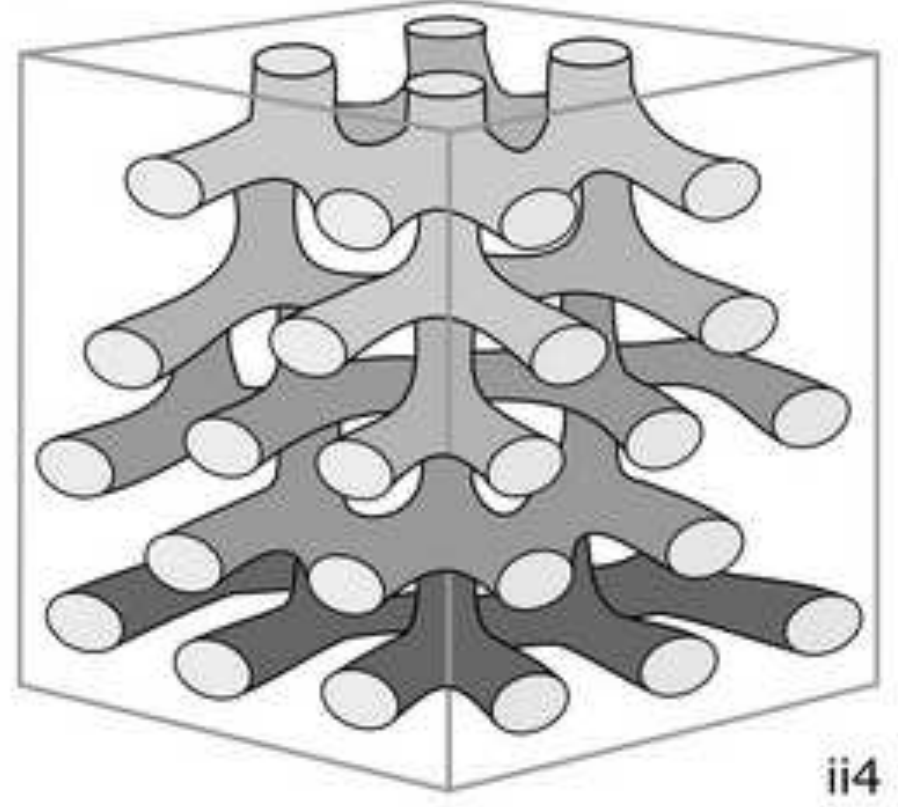

D

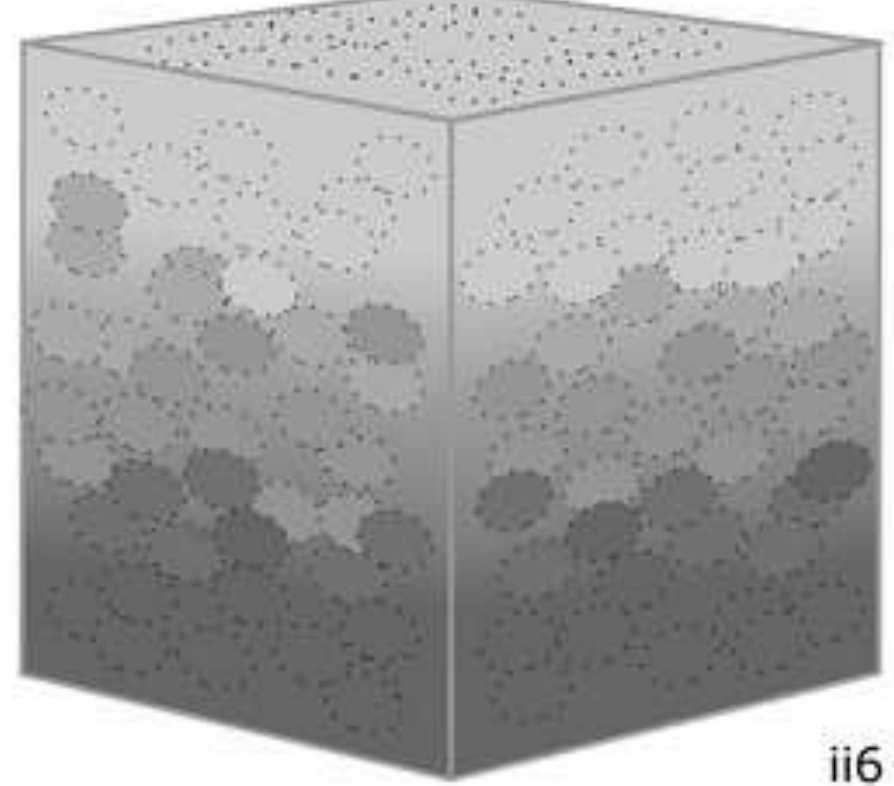




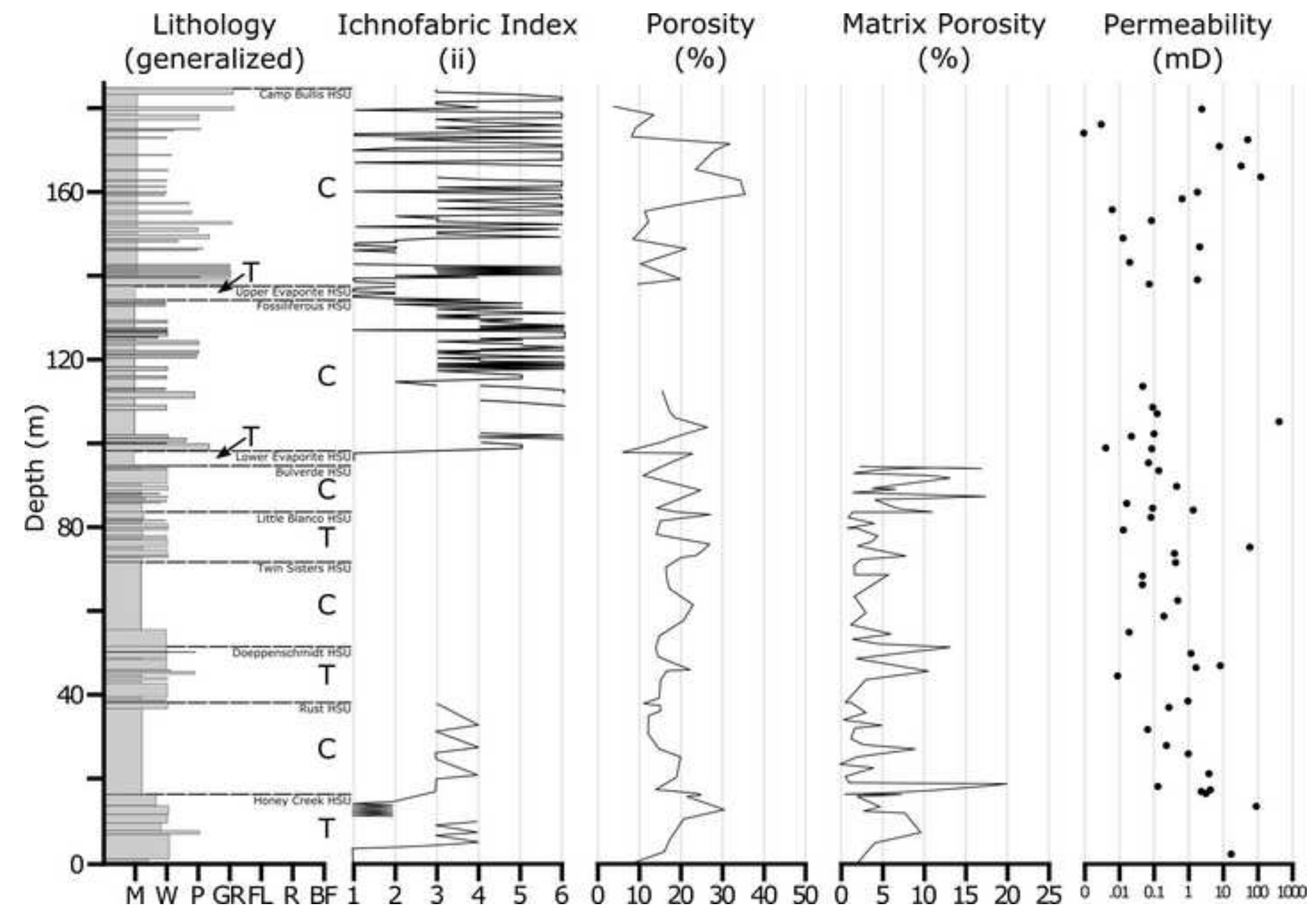




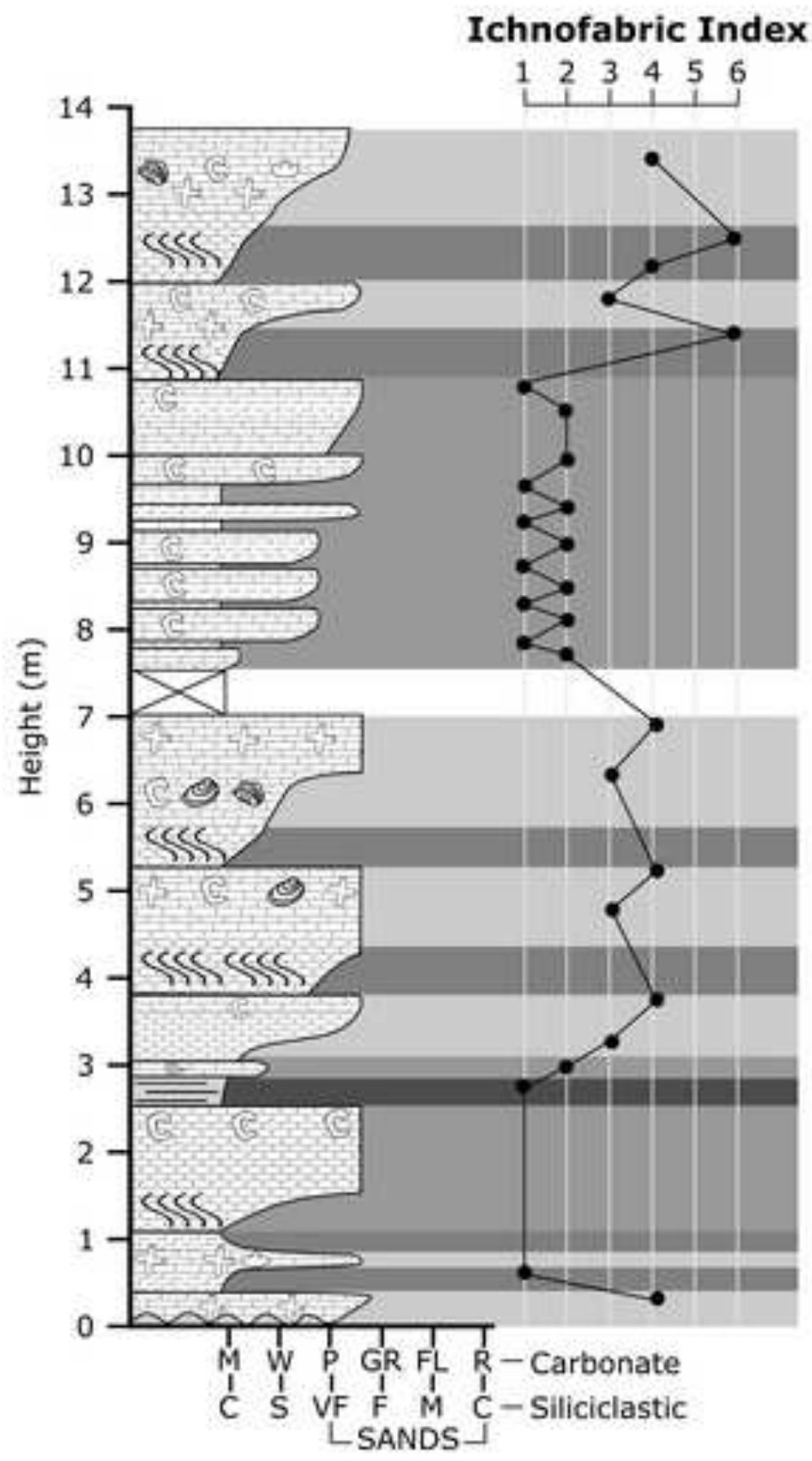

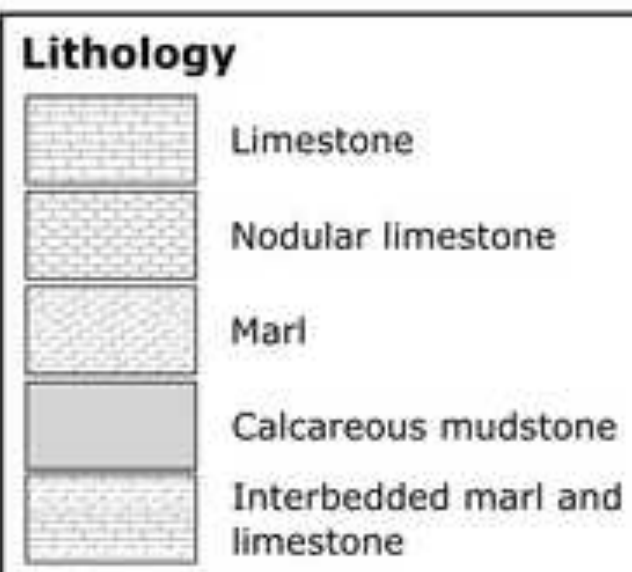

\section{Sedimentology}

Laminations

\section{Paleontology}

Oyster Shells

Bivalve Shells

Gastropod

Shells
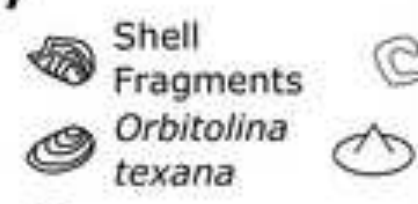

\section{Ichnology}

Thalassinoides $\left\{\begin{array}{l}\text { Nodular } \text { Bioturbation } \\ \text { Sis }\end{array}\right.$

\section{Hydrostratigraphy}

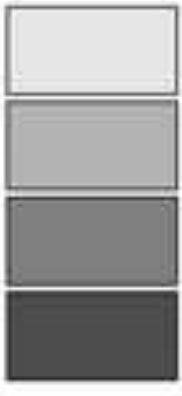

ii 3-4: Highly transmissive bed

ii1-2: Restricted

intergranular flow

ii5-6: Restricted flow

ii1: Highly restricted flow 


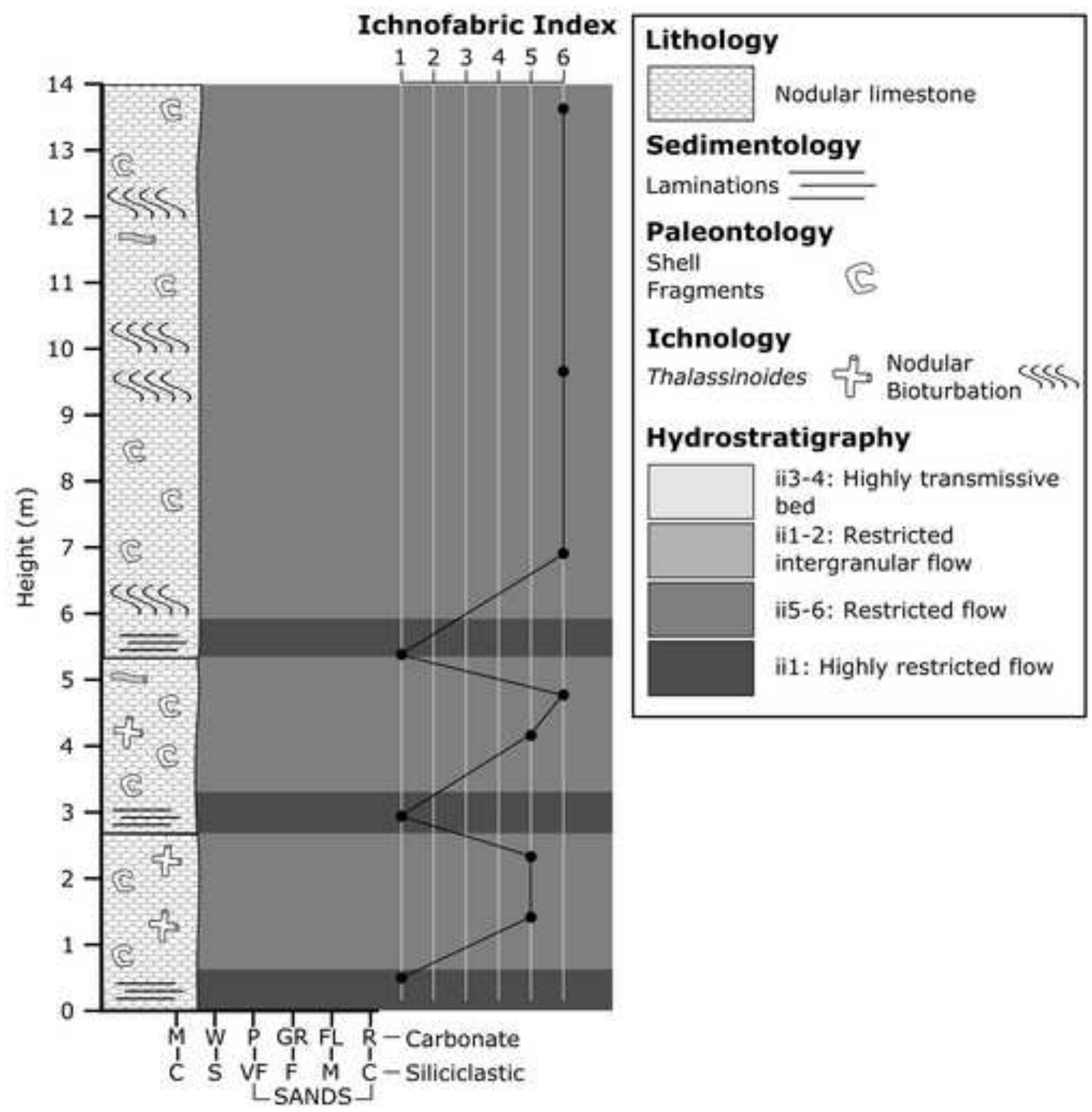




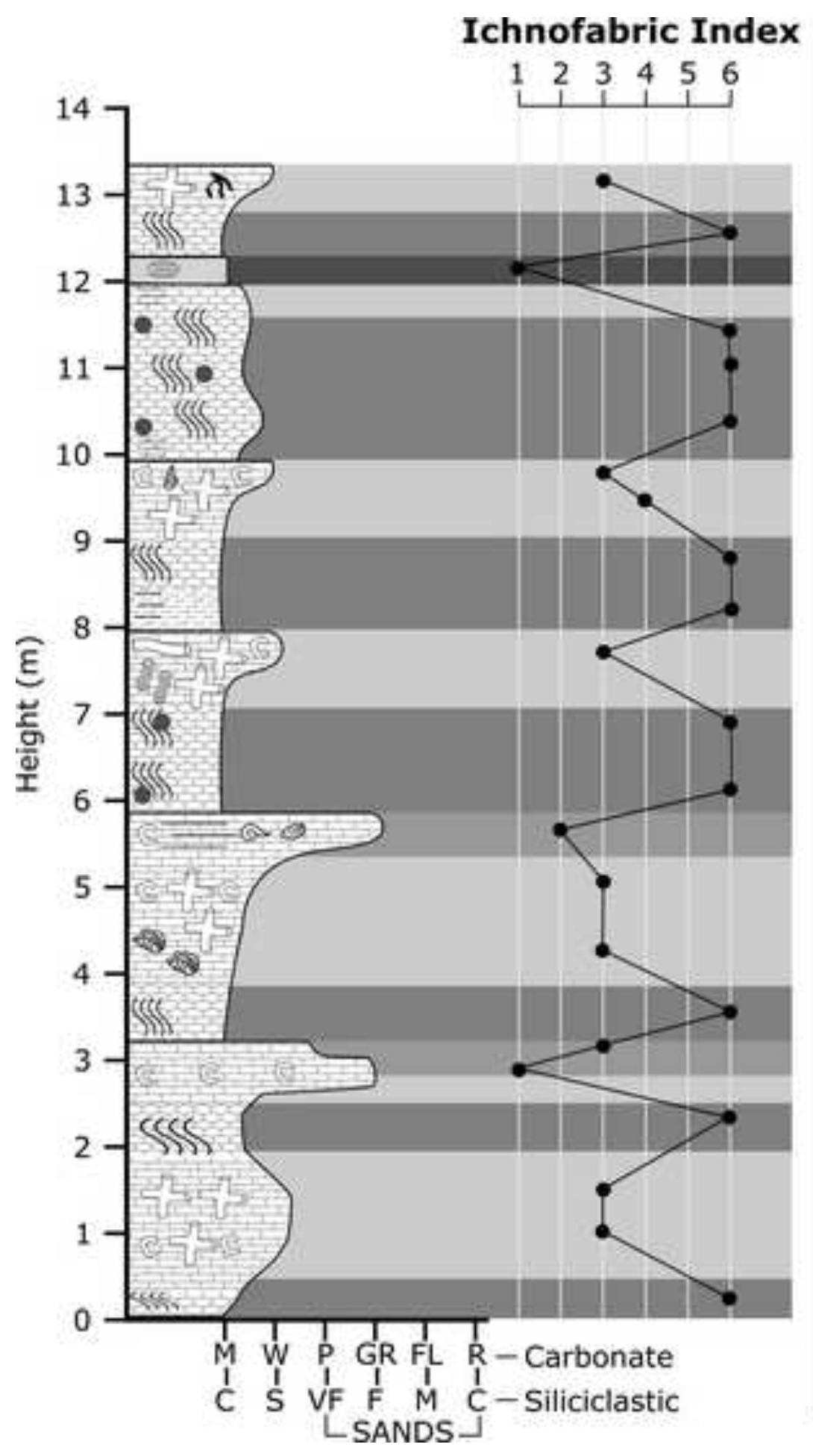

\section{Lithology}

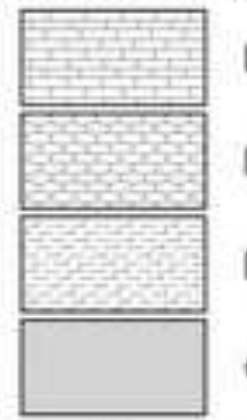

Limestone

Nodular limestone

Marl

Calcareous mudstone

\section{Sedimentology}

Laminations $=$ Mud clasts

Dendrites $\lambda$ Iron staining

Paleontology

Oyster Shells

Shell

Bivalve Shells

Gastropod

Shells

(C) Nerinea $s p$.

Ichnology

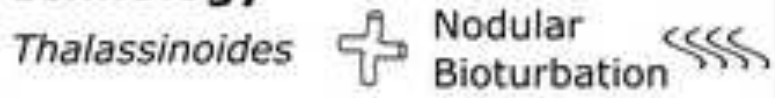

Planolites

Hydrostratigraphy

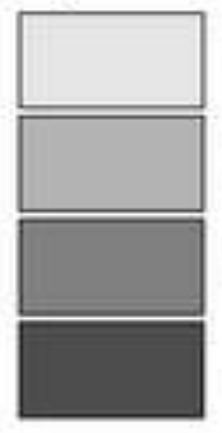

ii3-4: Highly transmissive bed

ii1-2: Restricted intergranular flow

ii5-6: Restricted flow

ii1: Highly restricted flow 


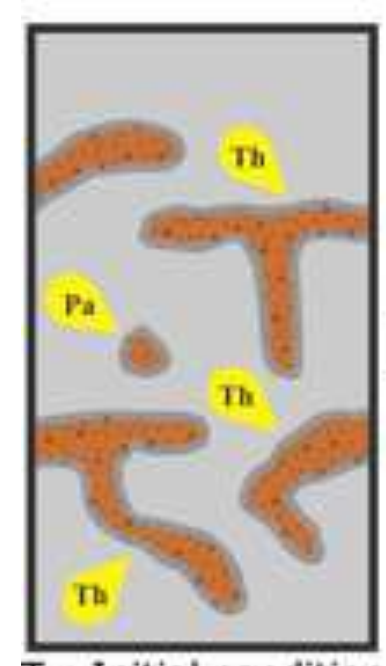

$\mathrm{T}_{1}$ : Initial condition

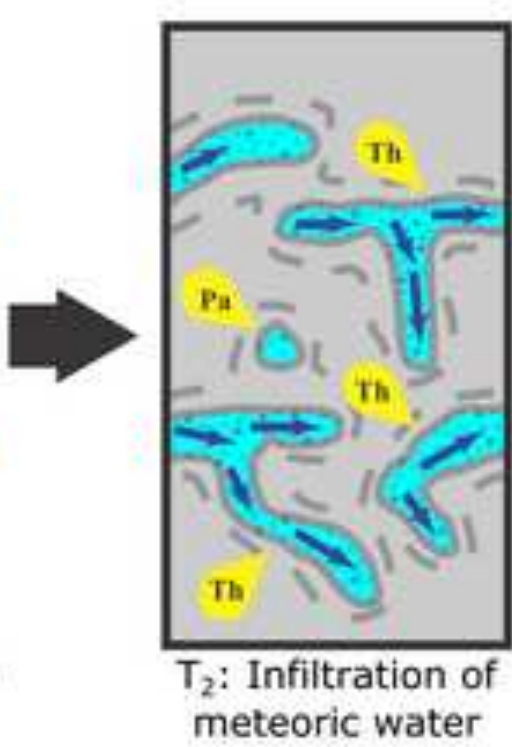

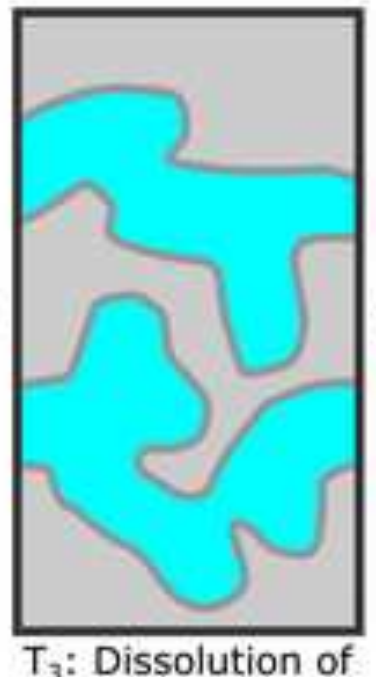

matrix material
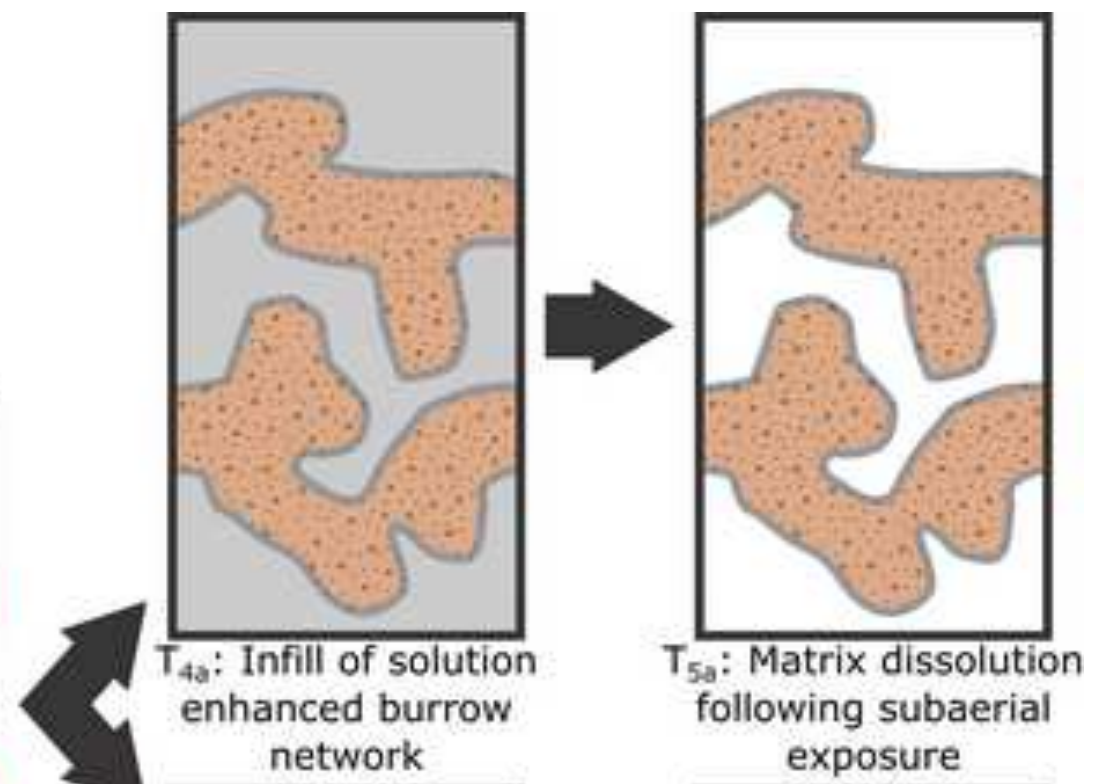

exposure

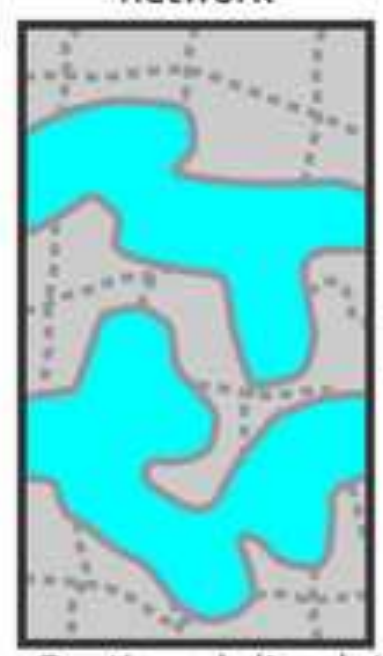

$T_{4 b}$ : Continued dissolution of matrix material

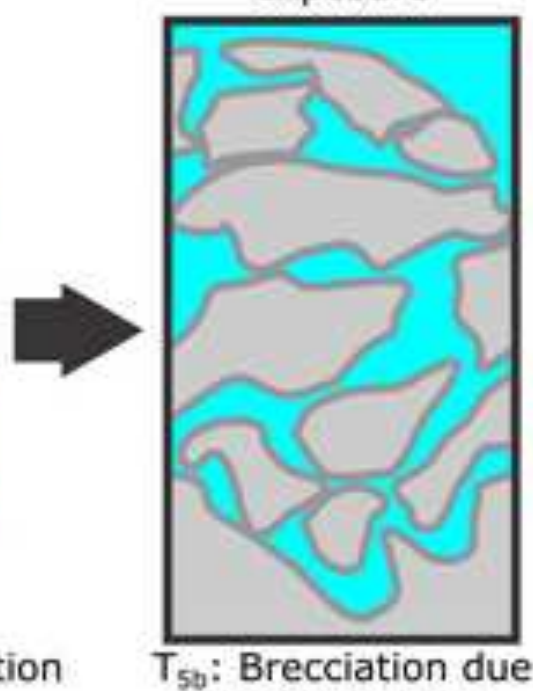

to compaction 